\title{
Geographical Assessment of Microalgae Biofuels Potential incorporating Resource Availability
}

\author{
Jason C. Quinn ${ }^{1 \star}$, Kimberly Catton ${ }^{2}$, Sara Johnson², \\ Thomas H. Bradley ${ }^{3}$
}

\author{
${ }^{1}$ Mechanical and Aerospace Engineering, 4130 Old Main Hill, Logan, Utah, USA, 84322 \\ ${ }^{2}$ Civil and Environmental Engineering, Colorado State University, Fort Collins, Colorado, USA, 80521 \\ ${ }^{3}$ Mechanical Engineering, Colorado State University, Fort Collins, Colorado, USA, 80521 \\ *Author for Correspondence: Phone: 435-797-0341, Fax: 435-797-2417, Email: Jason.Quinn@ usu.edu
}

\begin{abstract}
Previous assessments of the economic feasibility and large-scale productivity of microalgae biofuels have not considered the impacts of land and carbon dioxide $\left(\mathrm{CO}_{2}\right)$ availability on the scalability of microalgae-based biofuels production. To accurately assess the near-term productivity potential of large-scale microalgae biofuel in the US, a geographically realized growth model was used to simulate microalgae lipid yields based on meteorological data. The resulting lipid productivity potential of Nannochloropsis under large-scale cultivation is combined with land and $\mathrm{CO}_{2}$ resource availability illustrating current geographically feasible production sites and corresponding productivity in the US. Baseline results show that $\mathrm{CO}_{2}$ transport constraints will limit US microalgae based bio-oil production to $4 \%$ of the 2030 Department of Energy (DOE) alternative fuel goal. The discussion focuses on synthesis of this large-scale productivity potential results including a sensitivity analysis to land and $\mathrm{CO}_{2}$ resource assumptions, an evaluation of previous modeling efforts and their assumptions regarding the transportation of $\mathrm{CO}_{2}$, the feasibility of microalgae to meet DOE 2030 alternative fuel goals, and a comparison of the productivity potential in several key regions of the US.
\end{abstract}

Key Words: Biofuels; GIS; Microalgae; Model; Carbon Dioxide Abbreviations: Barrel (bbl), Carbon Dioxide $\left(\mathrm{CO}_{2}\right)$, Department of Energy (DOE), Geospatial information system (GIS)

\section{Introduction}

The current instability of global oil prices has motivated researchers and entrepreneurs to search for alternative sources of transportation fuel and energy [1]. In addition, the increase in the average global temperature due to greenhouse gas emissions has renewed interest in biofuels for use in transportation vehicles [2-4]. Compared to traditional terrestrial biofuel feedstocks, microalgae are characterized by higher solar energy yield, year-round cultivation, the use of lower quality or brackish water, the ability to utilize waste $\mathrm{CO}_{2}$, and the use of less- and lower-quality land [5-8]. Microalgae feedstock cultivation can be integrated with large-scale $\mathrm{CO}_{2}$ generating processes (e.g., combustion power plants, industrial fermentation facilities) to provide the microalgae with a carbon source that enables higher productivities than conventional crops [9]. These scalability advantages have led to an increased interest in microalgae as a feedstock for the production of biofuels, but the quantification of the productivity potential and economic viability of microalgae biofuels has proven difficult. 
Assessments of the productivity potential of microalgae-based biofuels reported in literature have varied by more than a factor of 17, primarily due to the use of low-order growth and productivity models $[7,10-13,6,14,15]$. Previous geographical evaluations of microalgae productivity potential have been based on a simplified growth model: the conversion of solar irradiance to biomass using a photosynthetic efficiency $[16,17]$. This growth modeling technique does not incorporate the effects of climate and temperature and thus cannot accurately represent a geographically dispersed, large-scale microalgae productivity potential. [18,17].

A variety of economic evaluations of the microalgae biofuels process have been performed with results varying from the $\$ 67$ a barrel reported by Huntley and Radalje [19] to the $\$ 823$ a barrel reported by Davis et al. [20] with others reporting values between these two extremes [21,22,12,13,23-29]. The majority of these studies not only used simplified growth models but made simplifying assumptions in terms of land and nutrient $\left(\mathrm{CO}_{2}\right)$ resource availability as well. One example is the common assumption that growth facilities and point source $\mathrm{CO}_{2}$ facilities will be collocated. A variety of studies identify the importance of site selection in terms of resource availability but fail to incorporate details for $\mathrm{CO}_{2}$ delivery in the analysis [12,22]. Other studies arbitrarily allocate minimal cost for $\mathrm{CO}_{2}$ concentration or procurement or transportation [23,13]. Benneman et al. [21] and Benneman and Oswald [26] are the two primary economic studies that incorporate a detailed calculation of the costs for $\mathrm{CO}_{2}$ transportation and on site delivery. Benneman et al. [21] concluded that $4.8 \mathrm{~km}$ is the maximum economically feasible distance for piping $\mathrm{CO}_{2}$, which corresponds to $13 \%$ of the cultivation facility's overall capital cost. In a follow-up study, Benneman and Oswald [26], reduced the feasible transport distance to $2.4 \mathrm{~km}$. Lundquist et al. [24] is the only recent study to include $\mathrm{CO}_{2}$ transportation cost with assumptions based on these previous studies [21] [26]. In general, economic studies of microalgae biofuels assume that $\mathrm{CO}_{2}$ will be a low-cost and readily available nutrient, without using modeling or analysis to validate the assumption.

Previous studies have modeled $\mathrm{CO}_{2}$ resource requirements based on a material balance but failed to model supply constraints or economic feasibility of the resource. To accurately evaluate the large-scale productivity potential of microalgae-based biofuels in the US, representative microalgae growth and lipid accumulation models validated with industrial scale outdoor growth data must be used in combination with geographically realized resource availability data [30,31]. This study presents the use of a photobioreactor growth model which utilizes historical meteorological data from 864 geographically diverse US locations to determine potential microalgae productivity and corresponding lipid percentage of a large-scale outdoor growth system. Productivity results are integrated with a resource assessment focused on land availability and $\mathrm{CO}_{2}$ resource availability defined through economic feasbility to illustrate the current large-scale potential of microalgae in the US. The discussion focuses on an evaluation of the capability of microalgae to meet $2030 \mathrm{DOE}$ alternative fuel goals, as well as sensitivity analysis to land and $\mathrm{CO}_{2}$ transport distances, and a critical assesment of states with high microalgae biofuel potential.

\section{Materials and Methods}

The following sections provide a basic overview of the photobioreactor growth model used to predict microalgae growth and lipid content, the data and criteria for the Geospatial Information System (GIS) land analysis, and details on the economic assumptions for determining feasible $\mathrm{CO}_{2}$ transport distances. A schematic of the simulation architecture including the biomass and lipid productivity based on species, reactor, metrological data, land, and resource analysis is presented in Fig. 1. The simulation integrates the microalgae growth model which predicts biomass and lipid production based on meteorological data, microalgae species characterization, reactor configuration, and reactor thermal modeling. Results from the microalgae growth model are integrated into the economic evaluation for $\mathrm{CO}_{2}$ transport distance and the data is then overlaid with land resource data to generate the dynamic maps presented. The microalgae growth model is coded in MatLab ${ }^{\circledR}$ with GIS data presentation performed using ArcGIS. 


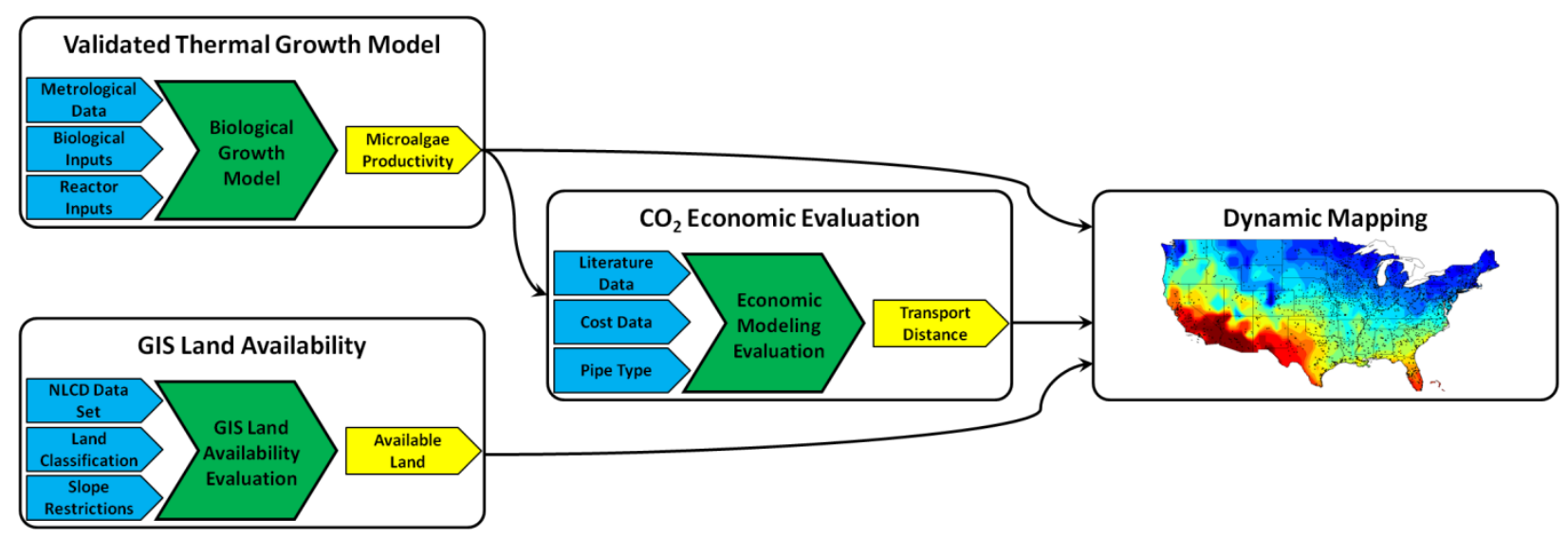

Fig. 1 Simulation architecture for resource assessment. The validated growth model includes species characteristics and photobioreactor geometry, water basin temperature and metrological data to predict biomass and lipid production. GIS land availability is defined based on land classification and maximum slope. $\mathrm{CO} 2$ economic evaluation incorporates literature and cost data with results from growth modeling. End results are dynamic maps illustrating current production locations and corresponding potential

\section{Photobioreactor thermal and growth model}

The photobioreactor modeled (Solix Biosystems Generation 3 photobioreactor) is submerged in a shallow pool of water (water basin) to provide structural and thermal stabilization (detailed descriptions of the system modeled are presented in the supplementary material). To incorporate the effects of temperature on growth, a thermal model of the water basin incorporating radiative, conductive, and convective heat balance was developed to estimate the temperature of the microalgae culture [32]. The water basin model uses inputs of solar radiation, drybulb temperature, dew-point temperature, wind speed, wind direction, cloud cover, and atmospheric pressure to calculate the heat balance and temperature of the water basin. The water basin temperature, which is assumed to be equivalent to the culture temperature, is then used as an input, along with corresponding meteorological data, to the microalgae growth model. The cultivation is assumed to shut down when the water basin freezes. Compete details on the growth model are presented in Quinn et al. [32].

The microalgae growth model, based on this photobioreactor architecture, incorporates 21 species- specific and reactor-specific characteristics to represent biomass growth and lipid accumulation. Examples of species specific characteristics include maximum growth rate, light saturation, and absorption coefficient. The characteristics of the reactor include spacing, depth, etc. The model has been shown to accurately represent the biomass and lipid production of Nannochloropsis oculata cultivated in Solix Generation 3 photobioreactors based on meteorological inputs and culture temperature [31].

Carbon fixation, based on the activity of the Rubisco enzyme, is the core of the microalgae growth model. The model incorporates light, temperature, and nutrients as primary factors, while also considering respiration losses and energy required for nutrient uptake. The productivity potentials presented in this study do not include land required for large-scale cultivation infrastructure such as materials storage, transportation, or process infrastructure. Instead, they are on a per photosynthetic area basis. The lipid potentials reported are in terms of total lipids produced and do not include potential losses from extraction or transesterification. All assumptions, validation, and details on the biological growth are presented in Quinn et al. [31].

\section{Historical weather data}

Historical hourly weather data from 1991 to 2005 from 864 US locations were input to the photobioreactor growth model [33]. The biological growth model used the primary inputs of microalgae temperature and solar radiation to predict the biomass and corresponding lipid content on an hourly basis at the simulated locations. Biomass and lipid yield results are presented on an annually averaged basis. 


\section{Geographical information system (GIS)}

The resulting productivity potential of the microalgae growth model at the 864 US locations was used as the base layer for the dynamic mapping. The results are interpolated for the US using an inverse distance weighting function in ArcGIS (ESRI) [34,32]. GIS data of land availability and $\mathrm{CO}_{2}$ resources were then overlaid on the productivity data to evaluate feasible microalgae cultivation sites in the US and the corresponding total productivity potential.

\section{Land resource criteria}

The National Land Cover Database from the Multi-Resolution Land Characteristics Consortium was used to evaluate the feasible locations for microalgae production based on land classifications. A scenario where microalgae cultivation was only allowed on land classified as barren, scrubland, shrubland, and grassland/herbaceous land was determined to be the baseline case, herein referred to as the barren case $[16,35,32]$. To eliminate land already designated for alternative purposes, the land cover data set was overlaid with federal land data, excluding cultivation in areas classified as national parks and forests, national recreation areas, federal research areas, and wilderness areas. Included in the potential cultivation sites were Bureau of Reclamation land and DOE sites. A sensitivity case including cultivation on pasture and forest land is also evaluated.

Land slope restrictions were determined based on recommendations from the techno-economic analysis literature with results indicating a baseline slope criteria where microalgae cultivation is only allowed on land of less than $2 \%$ slope $[21,36,37,32]$. Using GIS, slope data was extracted from Shuttle Radar Topography Mission at 90-m resolution digital elevation data [38]. Sensitivity to slope was evaluated through analysis allowing cultivation only on land of less than $1 \%$ slope and less than $5 \%$ slope.

Microalgae cultivation locations were limited to areas with greater than 2000 square meters of land (400 hectares) based on the recommendations of the microalgae biofuels economics literature. An equal area projection (North America Albers Equal Area Conical Projection) was used to determine the locations that satisfied the farm size criteria and land resource constraints. An analysis that expands the farm size to 4000 hectare was also performed. Details on the change in available land associated with this calculation are presented in the supplementary material.

\section{Economic evaluation for transport distance of carbon dioxide}

Carbon dioxide represents a critical nutrient for microalgae growth [9]. Two data sets, National Carbon Sequestration Database and Geographic Information System (NATCARB) and The Emissions \& Generation Resource Integrated Database (eGRID), were used in an effort to accurately identify the current $\mathrm{CO}_{2}$ point source locations in the US $[39,40]$. The integration of flue gas with microalgae cultivation has been successfully demonstrated, however the use of other point source $\mathrm{CO}_{2}$, such as a refinery, has not been extensively evaluated [9]. The following $\mathrm{CO}_{2}$ percentages in the corresponding streams were assumed: Amine (MEA)-100\%, Natural gas power plant-3\%, Cement-66\%, Manufacturing plant-14\%, Ethanol plant-87\%, Refinery-7.3\%. This analysis assumes that the microalgae biomass being produced is $50 \%$ carbon and there is no carbon loss in the transfer from the source to the microalgae. Initially $5280 \mathrm{CO}_{2}$-emitting locations were identified. Locations that could not provide the required $\mathrm{CO}_{2}$ for a 400 hectare growth facility based on a total daily $\mathrm{CO}_{2}$ output were removed from the data set resulting in 2899 possible point $\mathrm{CO}_{2}$ sources.

An economic assessment of the feasible transport distance of $\mathrm{CO}_{2}$ was performed based on an evaluation of the total capital cost of transport infrastructure (pipe and coupling) excluding installation costs. Installation costs were not included due to a large variability in installation cost as a function of geographic location. Previous economic studies from literature have estimated the capital cost for the installation of microalgae biofuel production systems with Sheehan et al. [28] reporting \$72,952 per hectare, Davis et al. [13] reporting \$99,949, and Lundquist et al. [24] reporting $\$ 253,963$ per hectare. A synthesis of these studies concluded that a moderate assumption for the current capital cost of a large-scale microalgae production is $\$ 100,000$ per hectare. In this study, $\mathrm{CO}_{2}$ is transported through concrete pipe with mortar joints as it represents the most economical solution of the variety of pipe options commercially available. Concrete pipe with $1.98 \mathrm{~m}$ (diameter) pre-cast mortar joints can be purchased for \$64 per meter (Personal Communication, Hancock Concrete Products, LLC.). This study evaluates three $\mathrm{CO}_{2}$ transportation scenarios: 1) the baseline case, which assumes a transport distance of $4.8 \mathrm{~km}$ corresponding to an overall capital cost 
increase of $8 \%$ 2) lower bound, which assumes a maximum transport distance of $1.6 \mathrm{~km}$ corresponding an increase of $2.7 \%$ of the overall capital cost, and 3) an upper bound, which assumes a maximum transport distance of $16 \mathrm{~km}$ corresponding an increase of 27\%. A survey of the literature indicates $4.8 \mathrm{~km}$ (baseline case) represented an economically preferable transport distance [21]. A more costly upper bound of $80 \mathrm{~km}$ or $137 \%$ the capital cost of the facility is also analyzed in the overall scalability assessments. Davis et al. [13] conclude that the current microalgae cultivation facility capital costs at $\$ 99,949$ per hectare are too high, even with their study excluding the costs to transport $\mathrm{CO}_{2}$. Thus, the conservative estimate assumed in this study of $4.8 \mathrm{~km}$ for an $8 \%$ increase for the transport of $\mathrm{CO}_{2}$, corresponding to the baseline case, is justified.

Circular buffers were generated at each $\mathrm{CO}_{2}$ site to reflect the amount of feasible land that each $\mathrm{CO}_{2}$ source could supply. A maximum buffer size of $1.6 \mathrm{~km}, 4.8 \mathrm{~km}$ (baseline case), $16 \mathrm{~km}$, and $80 \mathrm{~km}$ were evaluated. The analysis uses either the maximum buffer size based on the economic evaluation or a smaller buffer size that represented the land available based on $\mathrm{CO}_{2}$ supply. The states of Hawaii and Alaska were not included in this study because there were no large $\mathrm{CO}_{2}$ sources with high levels of lipid productivity $\left(>12 \mathrm{~m}^{3} \mathrm{ha}^{-1} \mathrm{yr}^{-1}\right)$.

\section{Results}

The results from this work are divided into four sections, i) a map illustrating the current realizable productivity potential in the continental US based on land resource assessment and farm size, ii) a map illustrating the feasible point source $\mathrm{CO}_{2}$ locations, iii) a map illustrating the current realizable productivity potential of microalgae in the continental US based on resource availability (land and $\mathrm{CO}_{2}$ ), and iv) a sensitivity analysis to land availability and $\mathrm{CO}_{2}$ transport distance.

\section{Lipid productivity for baseline land availability}

The modeled lipid productivity potential for microalgae cultivated in a photobioreactor including the baseline land availability (barren and $<2 \%$ slope) and minimum farm size requirement of 400 hectare without $\mathrm{CO}_{2}$ resource limitation is presented in Fig. 2. Restricting the minimum farm size from 1.25 hectares (land data resolution) to 400 hectares reduces the total available cultivation area by approximately $30 \%$. Increasing the minimum farm size to 4000 hectares reduces the total available cultivation area by an additional $35 \%$ relative to the base case of 400 hectares. As shown in Fig. 2, the US Desert Southwest has the highest lipid productivity due to its extended growing season and high solar radiation. Interestingly, the US Mountain West has a low productivity potential but is only a factor of 2 below the highest productivity rates observed in the southwest. 


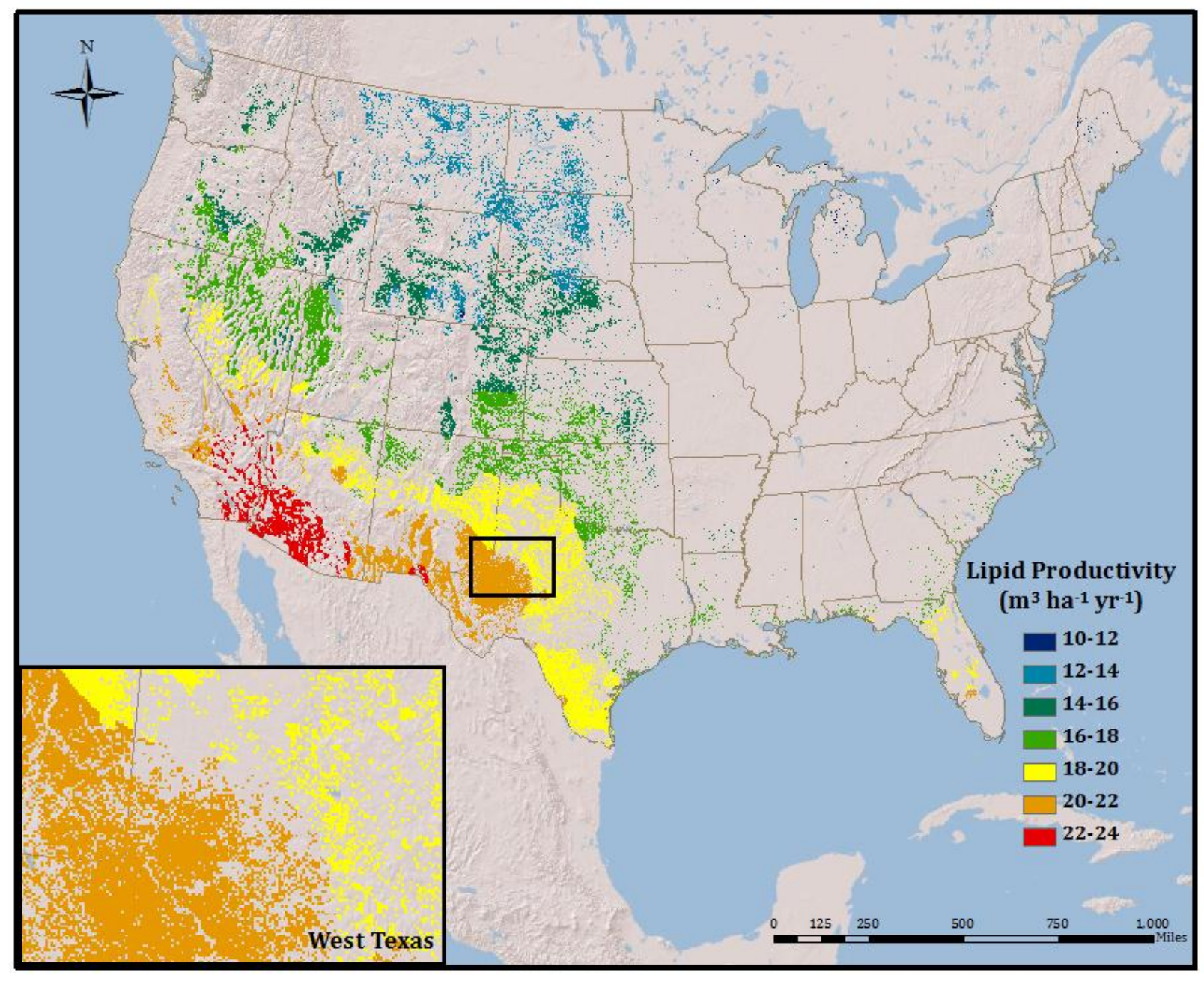

Fig. 2 Lipid productivity $\left(\mathrm{m}^{3} \mathrm{ha}^{-1} \mathrm{yr}^{-1}\right)$ incorporating minimum facility size and baseline land availability (Barren and less than $2 \%$ slope) without $\mathrm{CO}_{2}$ resource limitation. Each Pixel of color represents a minimum farm size of 400 hectares.

\section{Feasible carbon dioxide locations}

Feasible $\mathrm{CO}_{2}$ point sources based on the minimum growth size of 400 hectare are presented in Fig. 3. The majority of the $\mathrm{CO}_{2}$ point sources are shown to be located in the eastern US, whereas the majority of the available cultivation area is in the western US, as presented in Fig. 2. 


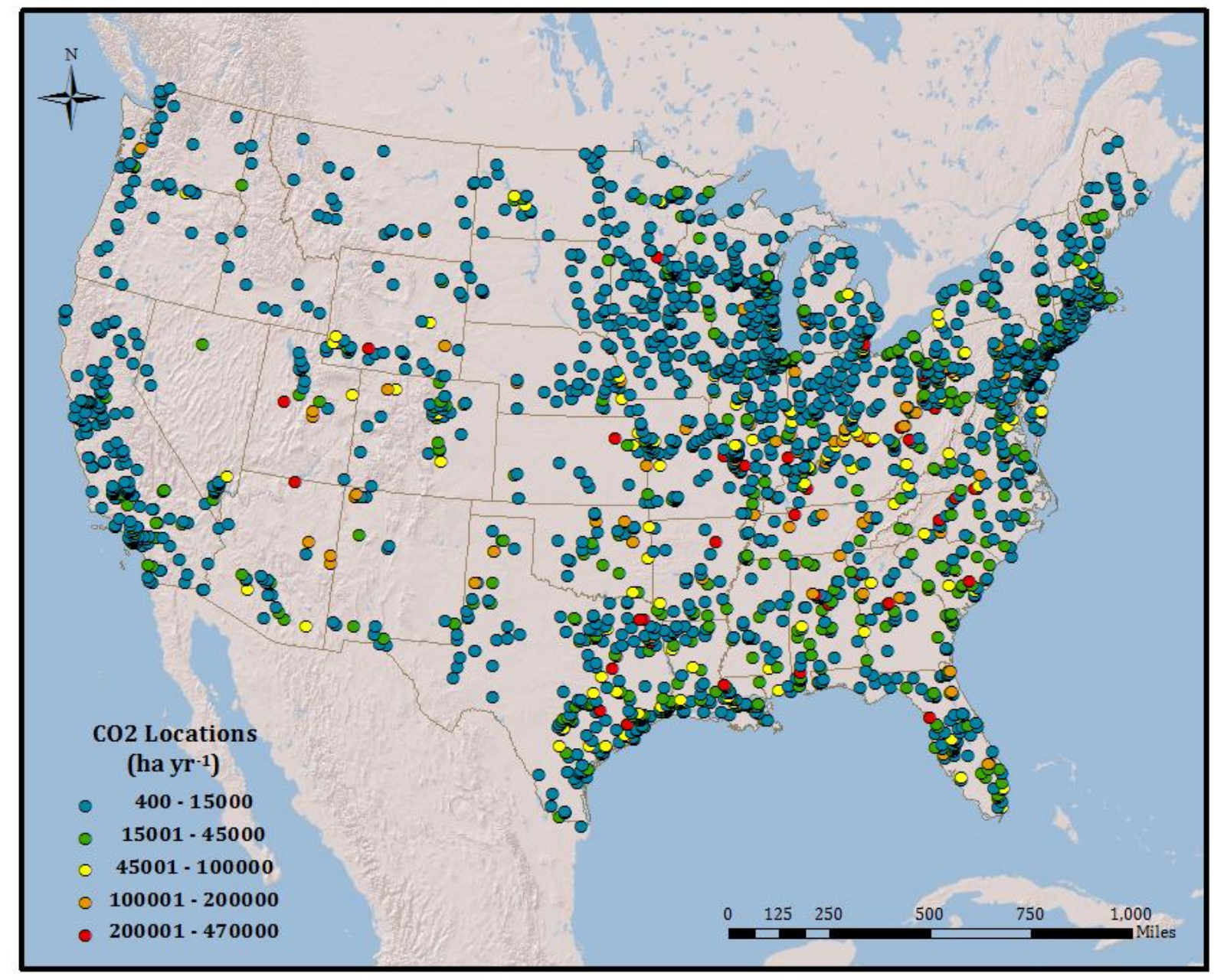

Fig. 3 Feasible $\mathrm{CO}_{2}$ point source locations for a minimum farm size of 400 ha in the continental US presented in ha of land that could be supplied by a single $\mathrm{CO}_{2}$ source without consideration of economic or transport constraints. Color represents serviceable hectares of land.

\section{Potential microalgae cultivation sites co-located with $\mathrm{CO}_{2}$}

The results of overlaying the lipid productivity map incorporating baseline land resource restrictions (Fig. 2) with a map including the baseline $4.8 \mathrm{~km}$ transport buffer around each $\mathrm{CO}_{2}$ source location (Fig. 3) is presented in Fig. 4. The location of each microalgae cultivation site is labeled in Fig. 4, while the lipid productivity $\left(\mathrm{m}^{3} \mathrm{ha}^{-1} \mathrm{yr}^{-1}\right)$

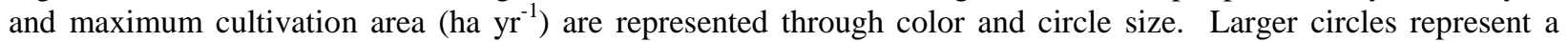
larger microalgae cultivation area within each buffer. Zonal statistics were computed in ArcGIS using the output map to determine the area of lipid productivity potential within each buffer. A total of 254 locations were identified as potential cultivation sites with the largest single farm being 5600 hectares. As shown in the extent frame, this example region of western Texas has 5 available $\mathrm{CO}_{2}$ sources, allowing for multiple microalgae cultivation facilities in each buffer. Each buffer contains a cultivation site with a lipid productivity of between $20-22 \mathrm{~m}^{3} \mathrm{ha}^{-1} \mathrm{yr}^{-1} \mathrm{with}^{-}$the differing areas of each cultivation facility results in differently sized circles on the nationwide map. 


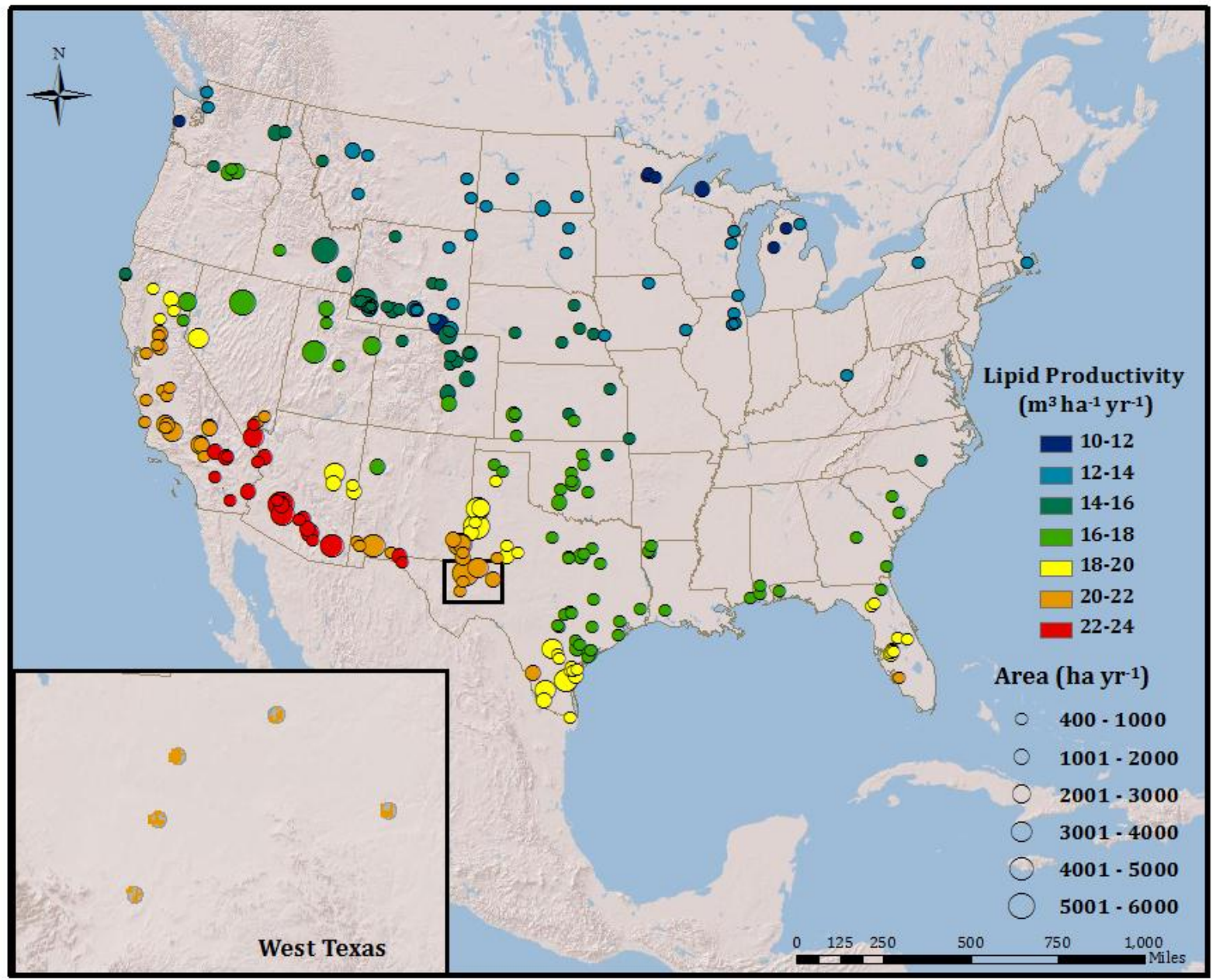

Fig. 4 Annual lipid productivity for barren land with less than 2\% slope, minimum farm size of 400 ha and $4.8 \mathrm{~km} \mathrm{CO} \mathrm{Cuffer}_{2}$ radius. Circle sizes are not actual size on US map. Insert is to scale and illustrates the high level of detail in the analysis.

\section{GIS land and $\mathrm{CO}_{2}$ transport sensitivity}

Sensitivity to the assumptions on land availability and $\mathrm{CO}_{2}$ transport distance were performed. The results for the most conservative scenario (A), cultivation on barren land of $<1 \%$ slope, with a maximum $\mathrm{CO}_{2}$ transport distance of $1.6 \mathrm{~km}$, and the most optimistic scenario presented (D), cultivation on barren, forested, pasture land, of $<5 \%$ slope with a maximum $\mathrm{CO}_{2}$ transport distance of $16 \mathrm{~km}$ are presented in Fig. 5. The number of feasible locations for cultivation dramatically changes with resource restrictions. For the most economically conservative and land-use restrictive case (Fig. 5 (A)), 13 cultivation locations were identified, while for the most unrestrictive case (Fig. 5 (D)), the number of locations increases to 2045. These can be compared to 254 locations available for the baseline case (Fig. 4). The total productivity for the scenarios (Fig. 5) are 0.9, 5.7, 252, and 1,606 million barrels (bbl) per calendar year for the A, B, C, and D scenarios respectively. Therefore, microalgae productivity potential is found to be very sensitive to assumptions regarding minimum slope, land cover restrictions, and $\mathrm{CO}_{2}$ transport distance with the productivity varying among these scenarios by a factor of 1784 . 

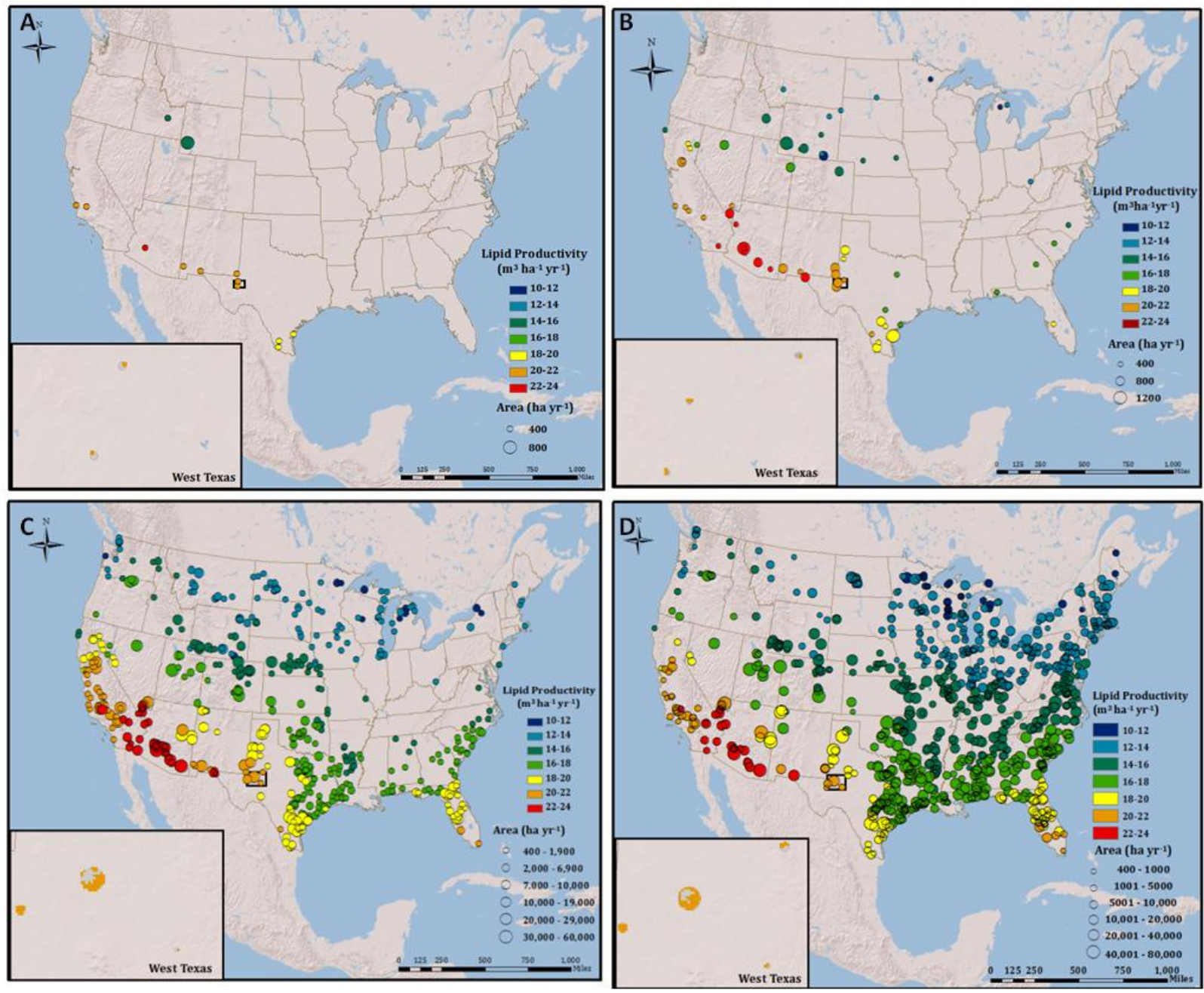

Fig. 5 Annual lipid productivity of A) Barren land, $<1 \%$ slope, maximum $\mathrm{CO}_{2}$ transport of $1.6 \mathrm{~km}$, B) barren land, $<2 \%$, maximum $\mathrm{CO}_{2}$ transport of $1.6 \mathrm{~km}, \mathrm{C}$ ) barren land, $<2 \%$ slope, maximum $\mathrm{CO}_{2}$ transport of 16 km, D) Barren, Forested, Pasture land, $<5 \%$ slope, maximum $\mathrm{CO}_{2}$ transport of $16 \mathrm{~km}$

\section{Discussion}

Based on these results, the potential of microalgae to meet DOE 2030 goals incorporating geographical relevant growth modeling that is integrated with GIS resource availability can be evaluated along with the critical evaluation of microalgae productivity potential in individual states.

\section{Microalgae productivity potential relative to DOE alternative fuel goals}

The US DOE has an alternative fuel goal of replacing 30\% ( 1 billion barrels) of the transportation fuel consumed in the US by 2030 [41]. Current scalability assessments for corn ethanol and soy based biodiesel require $385 \%$ and $148 \%$ of the current available farm land in the US, respectively, to meet the 2030 DOE alternative fuel goals [12]. The scalability of microalgae biofuels can also be critically evaluated based on this DOE alternative fuel goal, as shown in Table 1 . 
Table 1. Land availability and lipid production potential for the baseline and sensitivity scenarios. The baseline case (highlighted by bold text) represents cultivation on all US land with a land classification of barren, slope less than $2 \%$, minimum farm size of 400 ha and a $\mathrm{CO} 2$ transport distance of $4.8 \mathrm{~km}$. All scenarios include minimum farm size of 400 ha.

\begin{tabular}{|c|c|c|c|c|}
\hline $\begin{array}{l}\text { GIS Land } \\
\text { Classifications } \\
\text { Available for } \\
\text { Microalgae Cultivation }\end{array}$ & $\begin{array}{l}\text { GIS Slope } \\
\text { Classifications } \\
\text { Available for } \\
\text { Microalgae Cultivation }\end{array}$ & $\begin{array}{l}\mathrm{CO}_{2} \text { Transport } \\
\text { Distance } \\
\text { limitation }(\mathrm{km})\end{array}$ & $\begin{array}{l}\text { Total US Land } \\
\text { Available for } \\
\text { Microalgae } \\
\text { Cultivation } \\
\left(\cdot 10^{6} \text { hectares }\right)\end{array}$ & $\begin{array}{l}\text { Total US } \\
\text { Microalgae } \\
\text { based Lipid } \\
\text { Productivity } \\
\left(\cdot 10^{9} \mathrm{bbl}\right)\end{array}$ \\
\hline Barren & $<2 \%$ & 1.6 & 0.37 & 0.0057 \\
\hline Barren & $<2 \%$ & 4.8 & 0.28 & 0.0437 \\
\hline Barren & $<2 \%$ & 16 & 1.61 & 0.252 \\
\hline Barren & $<1 \%$ & 1.6 & 0.052 & 0.000855 \\
\hline Barren & $<1 \%$ & 4.8 & 0.055 & 0.00846 \\
\hline Barren & $<5 \%$ & 16 & 3.364 & 0.506 \\
\hline $\begin{array}{l}\text { Barren, Forested, } \\
\text { Pasture }\end{array}$ & $<5 \%$ & 16 & 11.78 & 1.606 \\
\hline
\end{tabular}

This modeling effort represents the current productivity potential of microalgae incorporating geographically relevant growth characteristics based on a photobioreactor architecture. Assuming a packing factor of 0.8 [7] and an average lipid productivity of $18 \mathrm{~m}^{3} \cdot \mathrm{ha}^{-1} \cdot \mathrm{yr}^{-1}, 10.5$ million hectares of land would be required to meet the DOE 2030 alternative transportation fuel goal of 1 billion barrels [41]. The results from this study show that using baseline GIS land, slope, and farm size criteria with a $\mathrm{CO}_{2}$ transport distance of $4.8 \mathrm{~km}$, the US has 0.28 million hectares of land available for microalgae cultivation. This land can potentially produce 44 million barrels of oil or $4.4 \%$ of the DOE 2030 alternative transportation fuel goal. These results are in stark contrast to prior and more optimistic scalability assessments of microalgae [12,6,42,27,32,5,43].

If the $\mathrm{CO}_{2}$ transport distance is increased to $80 \mathrm{~km}$, an economically disadvantaged distance (representing a $137 \%$ increase in cultivation facility capital costs), with the available land for cultivation including barren, forested and pasture with a slope restriction of less than 5\%, microalgae in the continental US could be cultivated on 13.4 million hectares of land corresponding to 1.8 billion barrels of oil or 1.8 times the DOE alternative fuel goal. These resource assumptions are not economically feasible based on the current state of the technology.

\section{Current productivity potential of microalgae state by state}

An analysis of the productivity potential of the top 10 states based on the baseline scenario (barren land, $<2 \%$ slope, minimum 400 hectare farm size, maximum $4.8 \mathrm{~km} \mathrm{CO}_{2}$ transport) with results from resource sensitivity are presented in Table 2. 
Table 2 Oil productivity potential in $10^{6} \mathrm{bbl}$ of the top 10 producing states in the US for the variety of resource restrictions. Land restrictions: B=Barren, $\mathrm{P}=\mathrm{Pasture}, \mathrm{F}=$ forested, Slope restrictions: less than 1\%, 2\%, and 5\%, Farm size: $400 \mathrm{ha}=$ minimum farm size of 400 hectares, $4000 \mathrm{ha}=$ minimum farm size of 4000 hectares, $\mathrm{CO}_{2}$ transport distance: maximum of $1.6 \mathrm{~km}, 4.8 \mathrm{~km}$, or $16 \mathrm{~km}$. Baseline case is presented in bold text.

\begin{tabular}{|c|c|c|c|c|c|c|}
\hline \multicolumn{7}{|c|}{ Resource Restrictions } \\
\hline State & $\mathrm{B},<2 \%$ & $\begin{array}{l}\mathrm{B},<2 \% \\
400 \mathrm{ha}\end{array}$ & $\begin{array}{l}\mathrm{B},<2 \%, \\
4000 \text { ha }\end{array}$ & $\begin{array}{l}\mathrm{B},<2 \% \\
400 \mathrm{ha} \\
4.8 \mathrm{~km}\end{array}$ & $\begin{array}{l}\text { Barren, }<1 \% \\
400 \mathrm{ha} \\
1.6 \mathrm{~km}\end{array}$ & $\begin{array}{l}\mathrm{B}, \mathrm{P}, \mathrm{F},<5 \% \\
400 \mathrm{ha} \\
16 \mathrm{~km}\end{array}$ \\
\hline Texas & 2574 & 1959 & 1344.2 & 11.17 & 0.337 & 294.1 \\
\hline California & 485 & 392 & 262.8 & 6.70 & 0.072 & 58.2 \\
\hline Arizona & 1007 & 888 & 707.9 & 6.68 & 0.078 & 84.9 \\
\hline New Mexico & 1257 & 1092 & 854.6 & 5.64 & 0.215 & 25.9 \\
\hline Wyoming & 394 & 263 & 115.9 & 2.99 & 0.102 & 29.1 \\
\hline Nevada & 738 & 680 & 551.5 & 2.47 & 0.0 & 27.5 \\
\hline Colorado & 425 & 324 & 192.4 & 1.80 & 0.0 & 27.4 \\
\hline Utah & 407 & 353 & 297.9 & 1.36 & 0.0 & 34.0 \\
\hline Montana & 338 & 179 & 54.5 & 0.45 & 0.0 & 9.9 \\
\hline Nebraska & 364 & 204 & 62.3 & 0.31 & 0.0 & 14.2 \\
\hline Continental US & 10277 & 7365 & 4762 & 43.7 & 0.855 & 1606 \\
\hline
\end{tabular}

In the evaluation of large-scale oil production from microalgae, the production decreases as resource restrictions are implemented as shown in Table 2. Based on the resource restriction of the baseline scenario, microalgae-based biofuels fail to meet DOE 2030 alternative fuel goals; only producing $4.3 \%$ of the alternative fuel goal. Each resource restriction evaluated decreases the overall productivity potential. The implementation of a minimum farm size of 400 hectare decreases the productivity potential by $28 \%$ relative to including all feasible barren land with less than $2 \%$ slope. Starting from feasible cultivation on barren land, less than $2 \%$ slope and a minimum farm size of 400 hectares and expanding the resource limitation to include a maximum transportation of $\mathrm{CO}_{2}$ to $4.8 \mathrm{~km}$ based on economic feasibility, microalgae productivity potential decreases by an additional factor of 169. Based on this study it is shown that resources such as $\mathrm{CO}_{2}$ represent a limiting factor on the scalability of microalgae biofuels.

The characteristics of intensive microalgae cultivation that enable its economic viability and environmental sustainability (high growth rates, low quality land use, high lipid productivity) are also the sources of its resource intensity. These results show that the economics of $\mathrm{CO}_{2}$ transport provide a hard economic limit to the productivity potential of highly-intensive microalgae agriculture. The primary pathways to reducing the impact of the resource limitations described in this study are to reduce the transport costs of $\mathrm{CO}_{2}$, and to reduce the dependence of microalgae cultivation on gaseous $\mathrm{CO}_{2}$. Researchers have proposed means to remove this resource limitation, including the cultivation of microalgae at low resource intensity and at low productivity [44], but this has been shown to have detrimental effects on the economic viability of microalgae biofuels production. Alternatively, the carbon source for microalgae could be a non-gaseous source that does not have strict transportation limitations, [45], but the economic feasibility of alternative carbon sources at industrial scale has yet to be investigated.

\section{Acknowledgments}

We gratefully acknowledge support from Solix Biosystems. 


\section{References}

1. Energy Information Administration (2010) World crude oil prices. http://tonto.eia.doe.gov/dnav/pet/pet_pri_wco_k_w.htm. Accessed 2010

2. Doney SC (2011) The growing human footprint on coastal and open-ocean biogeochemistry. Science 328 (5985):1512-1516. doi:10.1126/science.1185198

3. Kerr RA, Kintisch E (2010) Climate change NRC reports strongly advocate action on global warming. Science 328 (5982):1085-1085

4. Trenberth KE (2010) The climate fix what scientists and politicians won't tell you about global warming. Science 330 (6008):1178-1179

5. Schenk PM, Thomas-Hall SR, Stephens E, Marx UC, Mussgnug JH, Posten C, Kruse O, Hankamer B (2008) Second generation biofuels: High-efficiency microalgae for biodiesel production. BioEnergy Research 1 (1):20-43. doi:10.1007/s12155-008-9008-8

6. Wijffels RH, Barbosa MJ (2010) An outlook on microalgal biofuels. Science 329 (5993):796-799. doi:10.1126/science.1189003

7. Batan L, Quinn J, Willson B, Bradley T (2010) Net energy and greenhouse gas emission evaluation of biodiesel derived from microalgae. Environ Sci Technol 44:7975-7980. doi:10.1021/es102052y

8. Mata TM, Martins AA, Caetano NS (2010) Microalgae for biodiesel production and other applications: A review. Renewable and Sustainable Energy Reviews 14 (1):217-232

9. Li Y, Horsman M, Wu N, Lan CQ, Dubois-Calero N (2008) Biofuels from microalgae. Biotechnol Prog 24 (4):815-820. doi:10.1021/bp.070371k

10. Lardon L, Helias A, Sialve B, Stayer JP, Bernard O (2009) Life-cycle assessment of biodiesel production from microalgae. Environ Sci Technol 43 (17):6475-6481. doi:10.1021/es900705j

11. Campbell PK, Beer T, Batten D (2011) Life cycle assessment of biodiesel production from microalgae in ponds. Bioresour Technol 102 (1):50-56. doi:DOI:10.1016/j.biortech.2010.06.048

12. Chisti Y (2007) Biodiesel from microalgae. Biotechnol Adv 25 (3):294-306. doi:10.1016/j.biotechadv.2007.02.001

13. Davis R, Aden A, Pienkos PT (2011) Techno-economic analysis of autotrophic microalgae for fuel production. Applied Energy 88 (10):3524-3531

14. Frank ED, Han J, Palou-Rivera I, Elgowainy A, Wang MQ (2011) Life-cycle analysis of algal lipid fuels with the greet model. Center for Transportation Research, Energy Systems Division, Argonne National Laboratory, Oak Ridge, TN.

15. Scott SA, Davey MP, Dennis JS, Horst I, Howe CJ, Lea-Smith DJ, Smith AG (2010) Biodiesel from algae: Challenges and prospects. Curr Opin Biotechnol 21 (3):277-286

16. Maxwell EL, Folger AG, Hogg SE (1985) Resource evaluation and site selection for microalgae production systems. Solar Energy Research Institute:SERI/TR-215-2484

17. Wigmosta MS, Coleman AM, Skaggs RJ, Huesemann MH, Lane $L$ (2011) National microalgae biofuel production potential and resource demand. Water Resour Res 47:W0OH04. doi:10.1029/2010wr009966

18. Magnuson J (2010) Algal biofuels. Paper presented at the Washington State Bioenergy Research Symposium, Seattle, WA, 8 November 2010

19. Huntley $\mathrm{ME}$, Redalje DG (2007) $\mathrm{CO}_{2}$ mitigation and renewable oil from photosynthetic microbes: A new appraisal. Mitigation and Adaptation Strategies for Global Change 12:573-608

20. Davis R, Fishman D, Frank ED, Wigmosta MS, Aden A, Coleman AM, Pienkos PT, Skaggs RJ, Venteris ER, Wang MQ (June 2012) Renewable diesel from algal lipids: An integrated baseline for cost, emissions, and resource potential from a harmonized model. US Department of Energy Biomass Program. ANL/ESD/12-4, NREL/TP-5100-55431, PNNL-21437 
21. Benemann JR, Goebel RP, Weissman JC, Augenstein DC (1982) Microalgae as a source of liquid fuels. Final Technical Report, US Department of Energy, Office of Research:DOE/ER/30014-TR

22. Borowitzka M (1992) Algal biotechnology products and processes - matching science and economics. J Appl Phycol 4 (3):267-279. doi:10.1007/bf02161212

23. Grima EM, Belarbi EH, Fernandez FGA, Medina AR, Chisti Y (2003) Recovery of microalgal biomass and metabolites: Process options and economics. Biotechnol Adv 20 (7-8):491-515

24. Lundquist TJ, Woertz IC, Quinn NWT, Benemann JR (2010) A realistic technology and engineering assessment of algae biofuel production. Energy Biosciences Institute, Berkeley, CA.

25. Sun A, Davis R, Starbuck M, Ben-Amotz A, Pate R, Pienkos PT (2011) Comparative cost analysis of algal oil production for biofuels. Energy 36 (8):5169-5179. doi:10.1016/j.energy.2011.06.020

26. Benemann JR, Oswald WJ (1996) Systems and economic analysis of microalgae ponds for conversion of $\mathrm{CO}_{2}$ to biomass. Final report. March 1996.

27. Pienkos PT, Darzins A (2009) The promise and challenges of microalgal-derived biofuels. Biofuels Bioproducts \& Biorefining-Biofpr 3 (4):431-440. doi:10.1002/bbb.159

28. Sheehan J, Camobreco V, Duffield J, Graboski Ma, Shapouri H (1998) An overview of biodiesel and petroleum diesel life cycles. National Renewable Energy Laboratory, Golden, CO.

29. Williams PJL, Laurens LML (2010) Microalgae as biodiesel \& biomass feedstocks: Review \& analysis of the biochemistry, energetics \& economics. Energy \& Environmental Science 3 (5):554-590. doi:10.1039/b924978h

30. James SC, Boriah V (2010) Modeling algae growth in an open-channel raceway. J Comput Biol 17 (7):895-906. doi:10.1089/cmb.2009.0078

31. Quinn J, de Winter L, Bradley T (2011) Microalgae bulk growth model with application to industrial scale systems. Bioresour Technol 102 (8):5083-5092

32. Quinn J, Catton K, Wagner N, Bradley T (2012) Current large-scale us biofuel potential from microalgae cultivated in photobioreactors. BioEnergy Research 5 (1):49-60. doi:10.1007/s12155011-9165-z

33. Wilcox S (2007) 1991-2005 national solar radiation database. http://www.osti.gov/energycitations/servlets/purl/908182-AmuLTA/. Accessed 1 Oct 2010

34. ArcGIS (2010) World topographic map. http://www.arcgis.com/home/item.html?id=f2498e3d0ff642bfb4b155828351ef0e. Accessed 1 Nov 2010

35. U.S. Geological Survey (2001) National land cover database (NLCD 2001). http://www.mrlc.gov/nlcd_multizone_map.php. Accessed 15 Nov 2010

36. Lansford R, Hernandez J, Enis P, Truby D, Mapel C (1990) Evaluation of available saline water resources in new mexico for the production of microalgae. Solar Energy Research Institute:SERI/TR232-3597

37. Muhs J, Viamajala S, Heydorn B, Edwards M, Hu Q, Hobbs R, Allen M, Barton D, Fenk T, Bayless D, Cooksey K, Kuritz T, Crocker M, Morton S, Sears J, Daggett D, Hazlebeck D, Hassenia J (2009) A summary of opportunities, challenges, and research needs: Algae biofuels \& carbon recycling. Utah State University. www.utah.gov/ustar/documents/63.pdf. Accessed 28 Jan 2011

38. Consultative Group on International Agricultural Research (2010) Cgiar csi. www.cgiar-csi.org. Accessed Novemeber 2010

39. Environmental Protection Agency (2012) Egrid-carbon dioxide emissions from the generation of electric power in the united states. http://www.epa.gov/cleanenergy/energyresources/egrid/index.html. Accessed January 2012

40. National Energy Technology Laboratory (2012) National carbon sequestration database and geographic information system. http://www.netl.doe.gov/technologies/carbon_seq/natcarb/index.html. Accessed January 2012 
41. Department of Energy (2007) Alternative fuel transportation program; replacement fuel goal modification. Office of Energy Efficiency and Renewable Energy, vol 72. Department of Energy,,

42. Pate R, Klise G, Wu B (2011) Resource demand implications for us algae biofuels production scale-up. Applied Energy 88 (10):3377-3388. doi:10.1016/j.apenergy.2011.04.023

43. Weyer KM, Bush DR, Darzins A, Willson BD (2009) Theoretical maximum algal oil production. BioEnergy Research 3 (2):204-213. doi:10.1007/s12155-009-9046-x

44. Sturm BSM, Lamer SL (2011) An energy evaluation of coupling nutrient removal from wastewater with algal biomass production. Applied Energy 88 (10):3499-3506. doi:10.1016/j.apenergy.2010.12.056

45. Gardner R, Paeyton B, Cooksey K (2012) Bicarbonate trigger for inducing lipid accumulation in algal systems. USA Patent WO 2012/040698 A2, March 2012 


\section{Supplementary Material- Geographical Assessment of Microalgae Biofuels Potential incorporating Resource Availability}

Jason C. Quinn ${ }^{1 *}$, Kimberly Catton², Sara Johnson'2, Thomas H. Bradley ${ }^{3}$

\footnotetext{
${ }^{1}$ Mechanical and Aerospace Engineering, 4130 Old Main Hill, Logan, Utah, USA, 84322

${ }^{2}$ Civil and Environmental Engineering, Colorado State University, Fort Collins, Colorado, USA, 80521

${ }^{3}$ Mechanical Engineering, Colorado State University, Fort Collins, Colorado, USA, 80521

*Author for Correspondence: Phone: 435-797-0341, Fax: 435-797-2417, Email: Jason.Quinn@ usu.edu
}

\section{Photobioreactor Growth Facility}

The facility modeled is representative of the Solix generation 3 photobioreactor. The photobioreactor is thermally and structurally supported in a water basin as illustrated in Fig. S1.

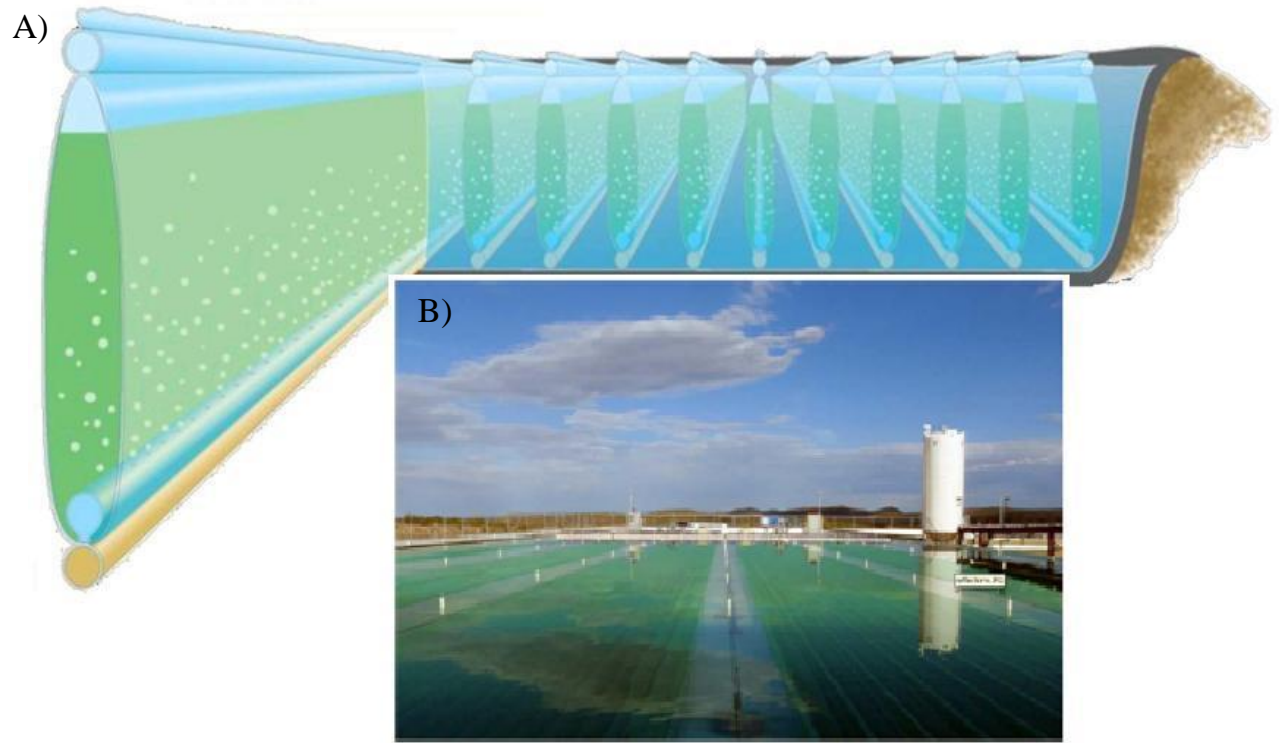

Fig. S1 A) schematic drawing of photobioreactors. B) Image of cultivation system modeled courtesy of Solix Biosystems. Photobioreactors are structurally and thermally supported in a water basin. The water basin pictured is approximately $40 \mathrm{~m} \times 25 \mathrm{~m} \times 1.2 \mathrm{~m}$.

The system is not actively thermally managed (no heat or cooling is supplied). In terms of the temperature, the photobioreactors will be well mixed based on sparge air mixing with no thermal stratification in the photobioreactors. The basins which represent the structural and thermal support component of the system does not get mixed by sparge air thus could have the potential to have thermal stratification as it represents over $70 \%$ of the thermal mass of the system. More details on the facility are presented in Quinn et al. [1]. The system modeled is 
representative of the outdoor research and development facility that has been in continuous operation since 2008 in Fort Collins, CO [2].

\section{Equal Area Projection: 112 m resolution vs $2000 \mathrm{~m}$ resolution}

The land resource analysis included the adaptation of a minimum farm size. A variety of researchers have performed techno-economic and life-cycle work that utilize a unit farm size [3-8]. Wigmosta et al. [7] assume a 490 hectare facility that incorporates 90 hectares of infrastructure. Davis et al. [5] model a facility that is 2909 hectares with two thirds growth one third processing in their economic assessment. Frank et al. [6] performed a lifecycle assessment that is based on a 4712 hectare facility. Lundquist et al. [8] model a 100 and a 400 hectare facility. Benneman et al. [3] uses a base case farm size of 800 hectares. Further analysis in Benneman and Oswald [4] used a base case size of 400 hectares. Based on this survey of the literature a base case facility size of 400 hectares was used in this study. The resolution of the land classification data was changed from $112 \mathrm{~m}$ to $2000 \mathrm{~m}$. An evaluation of the change in available land and corresponding productivity is presented in Table S1.

Table S1. US total production based on the land cover data at a resolution of $112 \mathrm{~m}$ and $2000 \mathrm{~m}$

\begin{tabular}{lllll}
\hline \multicolumn{2}{c}{ Production Area (ha) } & \multicolumn{2}{c}{ Lipid Productivity (bbl) } \\
\hline & Barren & Barren, Forest, Pasture & Barren & Barren, Forest, Pasture \\
& $2 \%$ & $5 \%$ & $2 \%$ & $5 \%$ \\
$112 \mathrm{~m}$ & $6.89 \mathrm{E}+07$ & $2.58 \mathrm{E}+08$ & $1.02 \mathrm{E}+10$ & $3.58 \mathrm{E}+10$ \\
$2000 \mathrm{~m}$ & $4.79 \mathrm{E}+07$ & $2.35 \mathrm{E}+08$ & $7.38 \mathrm{E}+09$ & $3.30 \mathrm{E}+10$ \\
\hline
\end{tabular}

Decreasing the resolution of the land cover data such that only farms of 400 hectares ( $2000 \mathrm{~m}$ by $2000 \mathrm{~m}$ ) are represented decreases the overall productivity. The available land and corresponding productivity for the baseline case (Barren, <2\%) decreases by approximately $30 \%$. A visual representation of change in land is presented in Fig. S2. 

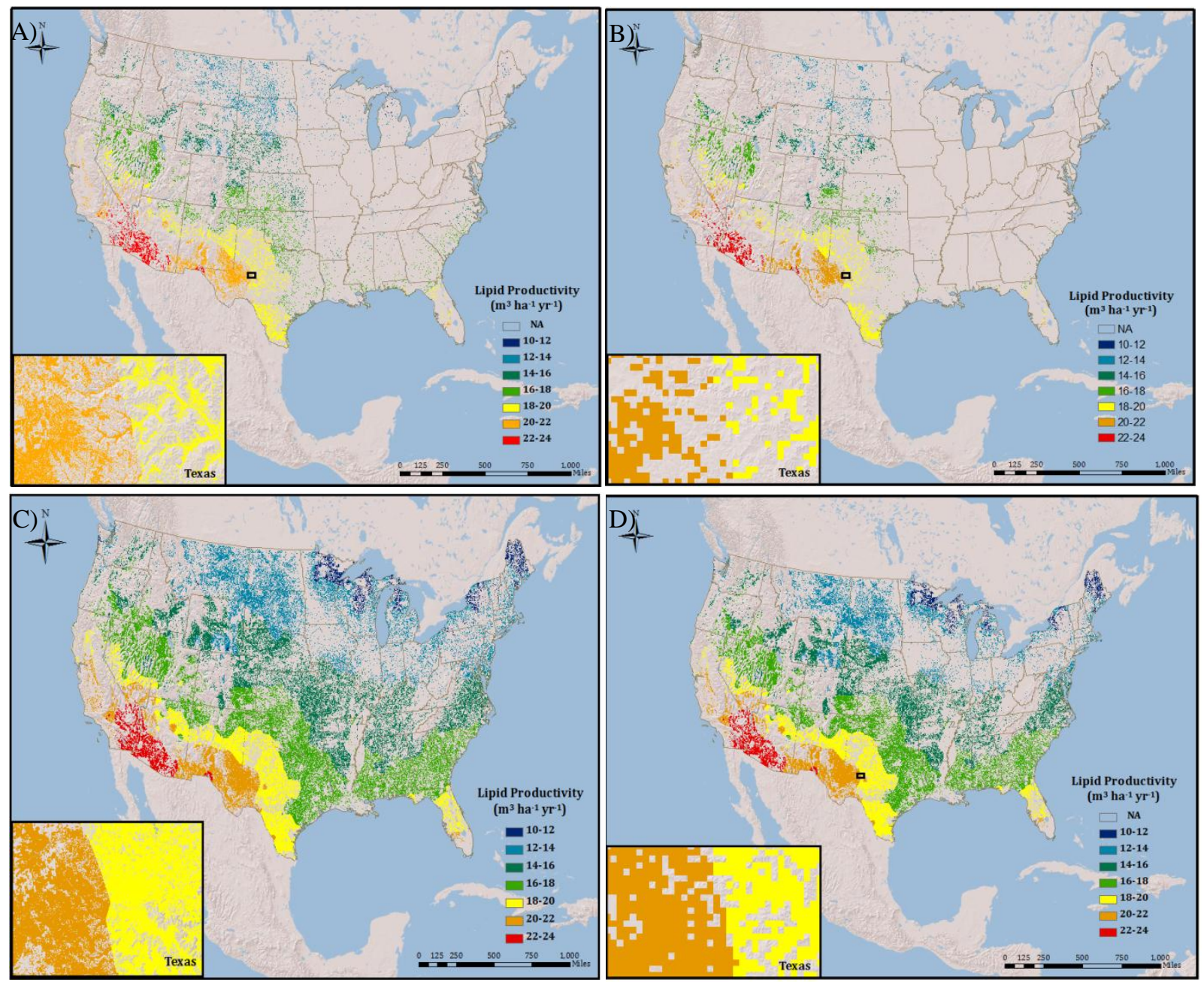

Fig. S2. A) Baseline land availability scenario (Barren, $<2 \%$ slope) with 1.2 hectare farm size. B) Baseline land availability scenario (Barren, $<2 \%$ slope) with 400 hectare farm size. C) Barren, forest, and pasture land with $<5 \%$ slope at 1.2 hectare farm size D) Barren, forest, and pasture land with $<5 \%$ slope at 400 hectare farm size

As illustrated in Fig. S2, the requirement of a minimum farm size decreases the available land for both land scenarios considered. The change in available land is expected as small farms (less than 400 hectares) are not feasible based on economy of scale.

\section{Dynamic Maps}

Dynamic maps for the various sensitivity cases were generated and presented below. The first figures do not include the resource evaluation of $\mathrm{CO}_{2}$ and just includes land resource assessment and productivity potential. 


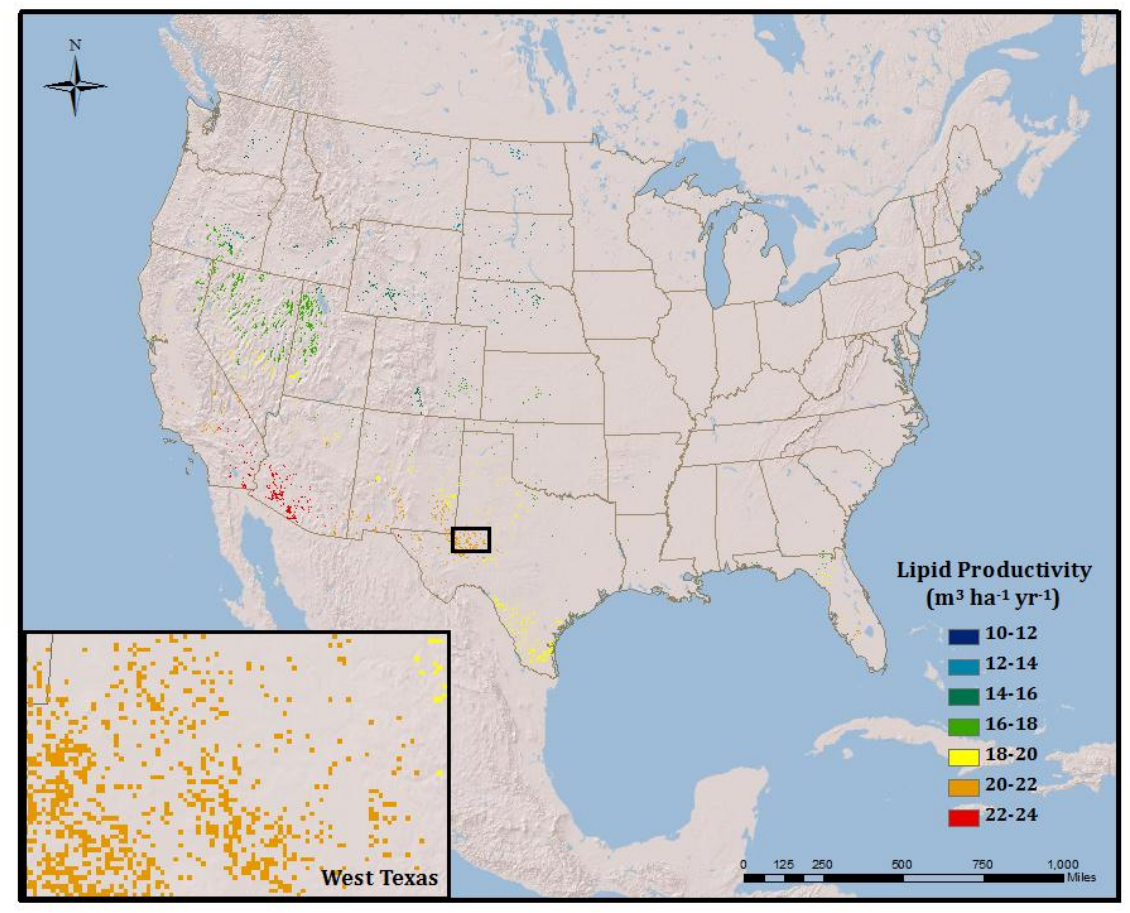

Fig. S3. Barren land, <1\% slope, minimum farm size of 400 ha, no CO2 buffers

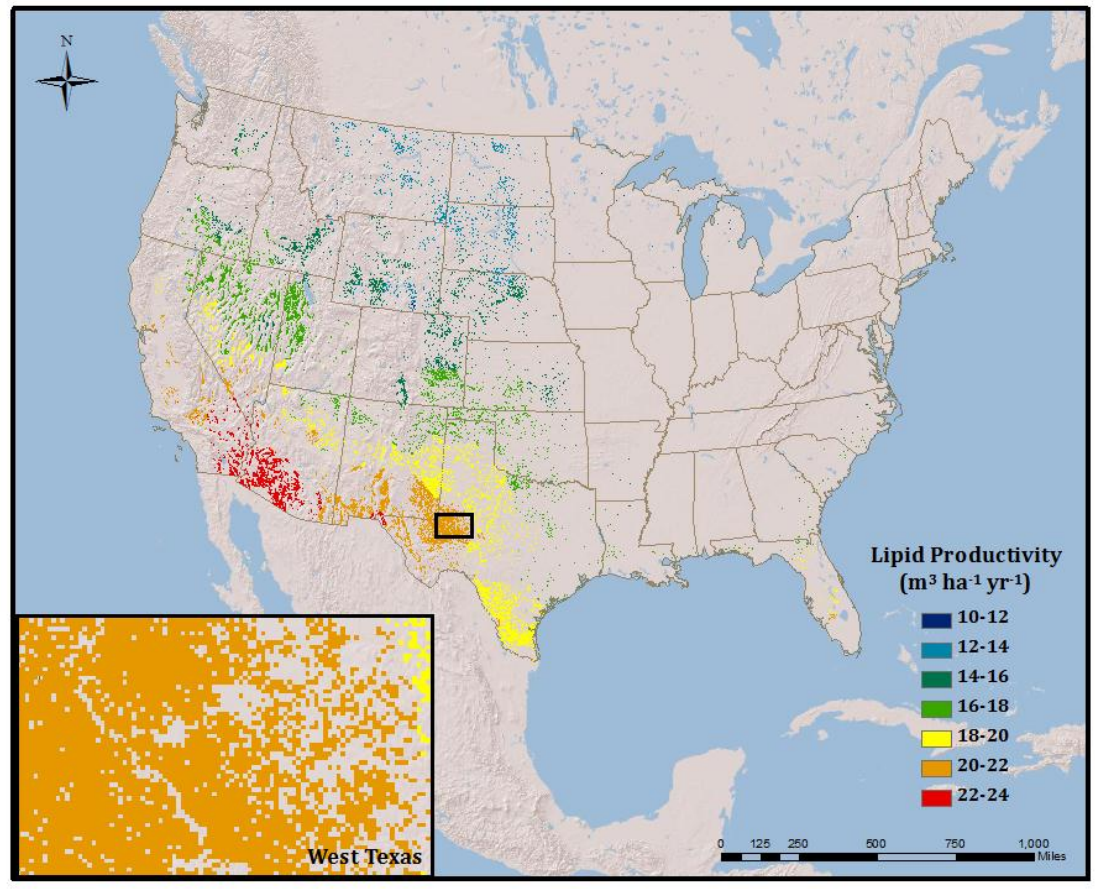

Fig. S4. Barren land, <2\% slope, minimum farm size of 400 ha, no CO2 buffers 


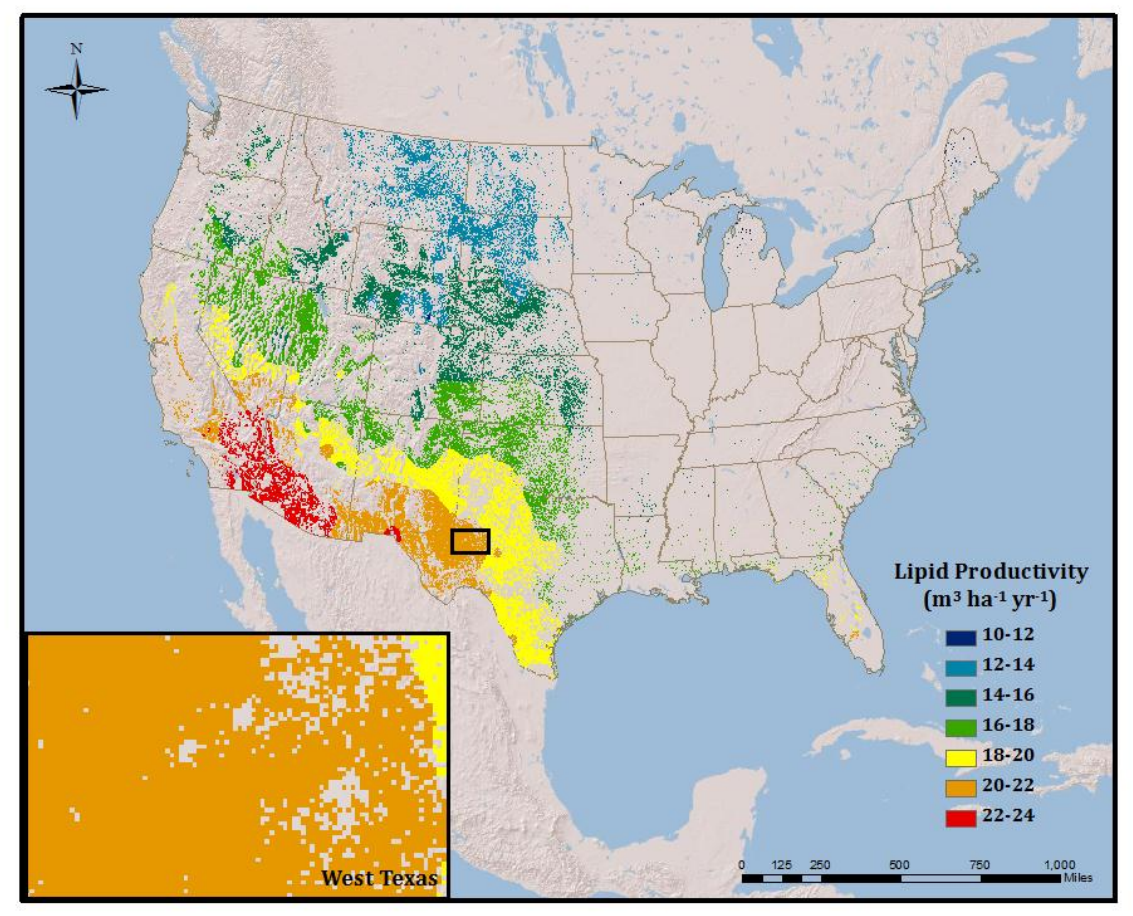

Fig. S5. Barren land, <5\% slope, minimum farm size of 400 ha, no CO2 buffers

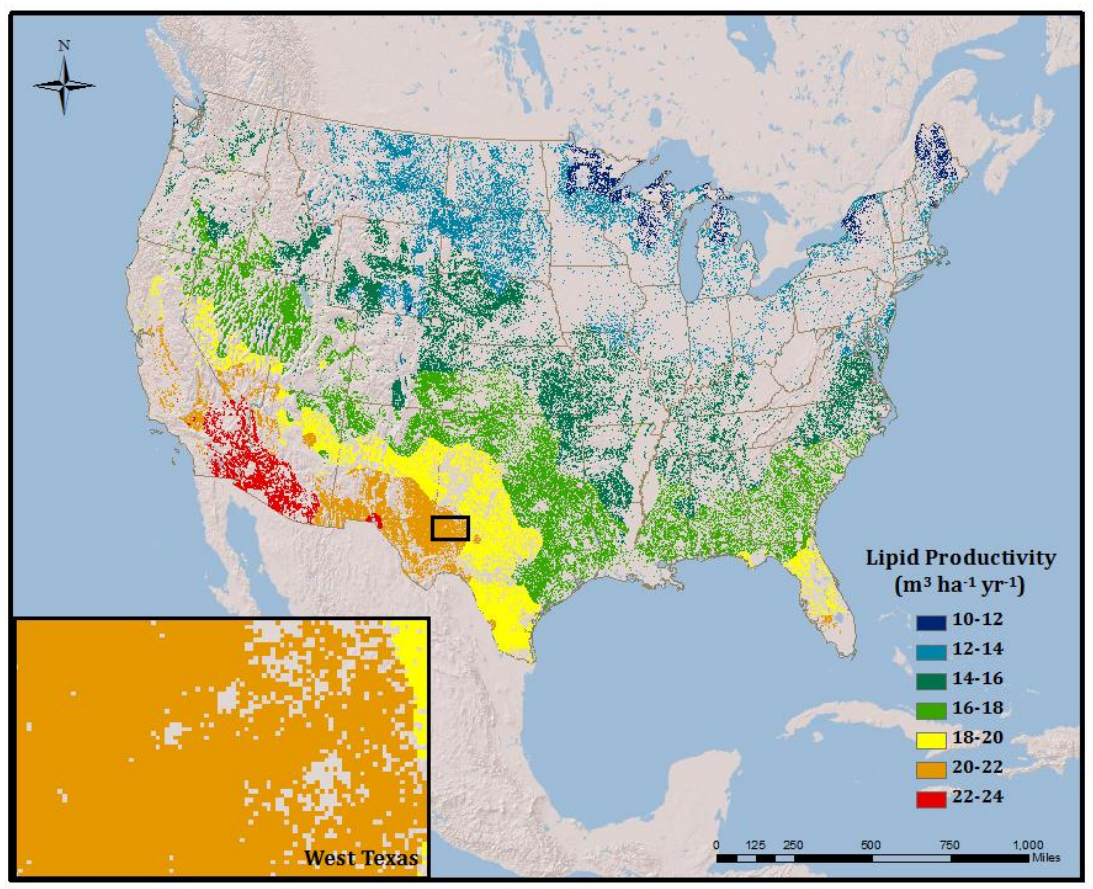

Fig. S6. Barren, pasture, and forest land, <5\% slope, minimum farm size of 400 ha, no CO2 buffers 
The figures above demonstrate the increase of available land and lipid productivity area as the land type and slope are expanded. The increase in microalgae potential growth area can be seen in the extent window of west Texas as the allowable slope is increased. Potential area in west Texas does not change between Fig. 3 and Fig. 4 because the slope remains constant and there was no addition of forest or pasture land.

The inclusion of $\mathrm{CO}_{2}$ as a resource limitation dramatically decreases the available land. The following figures present dynamic maps that include productivity potential, land resource assessment and $\mathrm{CO}_{2}$ transport limitations.

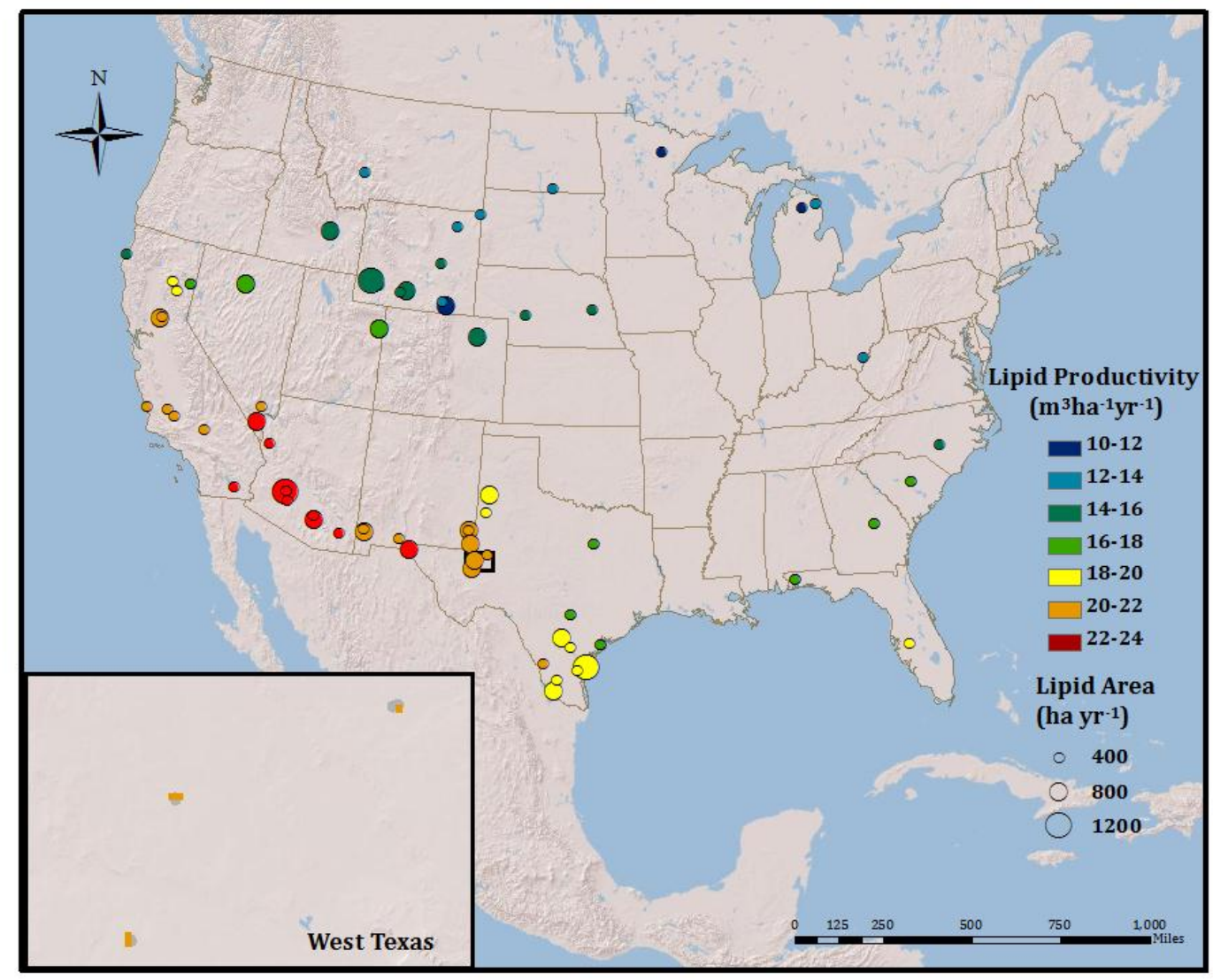

Fig. S7. Barren land, <2\% slope, minimum farm size of 400 ha, $1.6 \mathrm{~km}$ buffer

The resource restrictions of barren land with less than $2 \%$ slope and a $1.6 \mathrm{~km}$ buffer around the $\mathrm{CO}_{2}$ sources is shown in Fig. S7. In the extent window, the grey circles represent the $1.6 \mathrm{~km}$ buffer and only one or two lipid productivity areas located within each. The maximum area within one buffer for this case is 1200 ha which would be three colored cells at 400 ha each. Individual $\mathrm{CO}_{2}$ locations were difficult to see on the nationwide map due to the small buffer size of $1.6 \mathrm{~km}$, so the lipid productivity $\left(\mathrm{m}^{3} \mathrm{ha}^{-1} \mathrm{yr}^{-1}\right)$ and maximum area $\left(\mathrm{ha} \mathrm{yr}^{-1}\right)$ were represented by color and circle size. Larger circles represent more microalgae potential area within each buffer. 


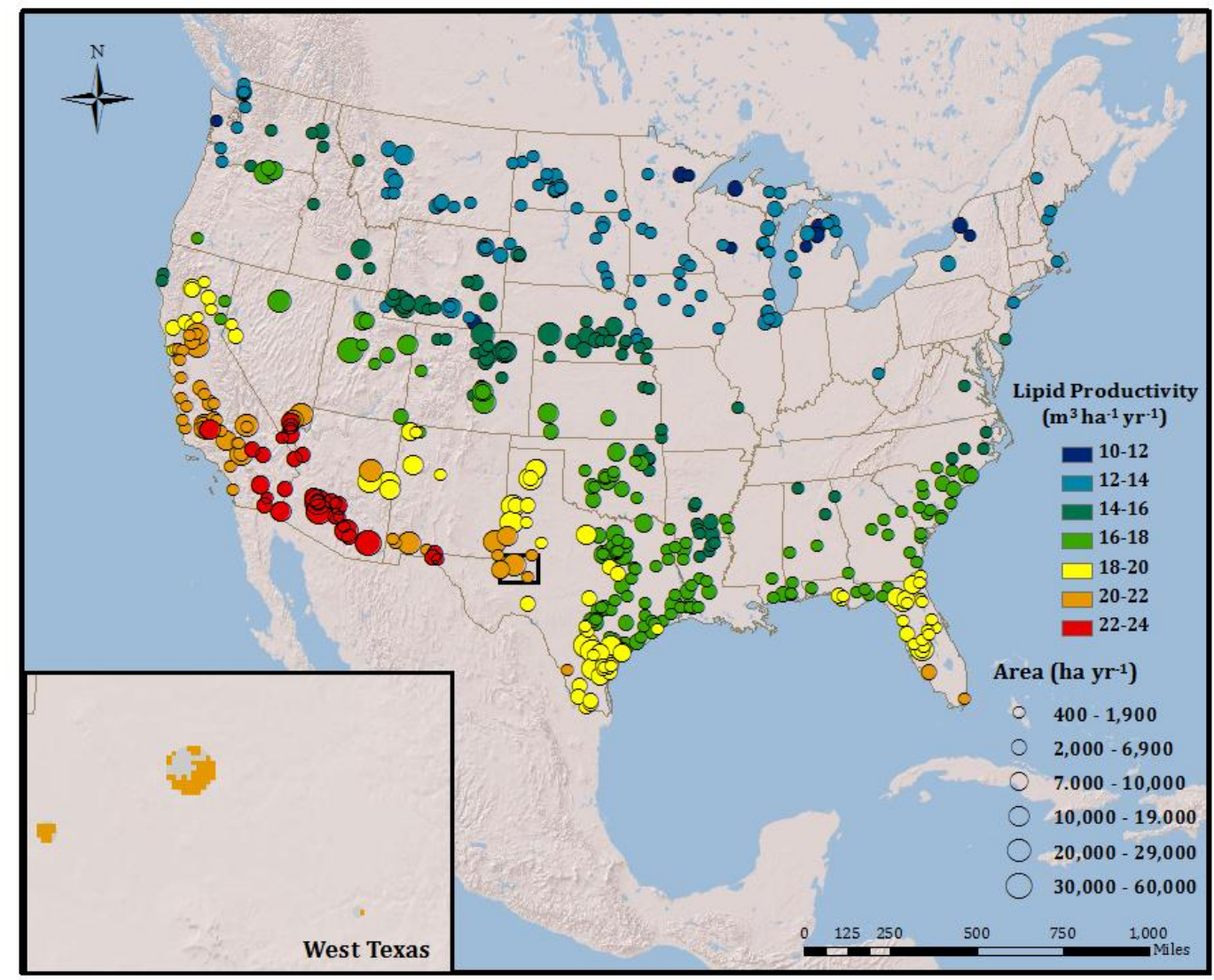

Fig. S8. Barren land, $<2 \%$ slope, minimum farm size of 400 ha, $16 \mathrm{~km}$ buffer

Resource restrictions of barren land with less than $2 \%$ slope, a minimum farm size of 400 ha and $16 \mathrm{~km}$ buffer is shown in Fig. S8. The sixteen kilometer buffers are the grey circles show in the extent window, showing a closer view of west Texas. At this buffer size, it is easier to see the different number of potential growth facilities within each buffer. 


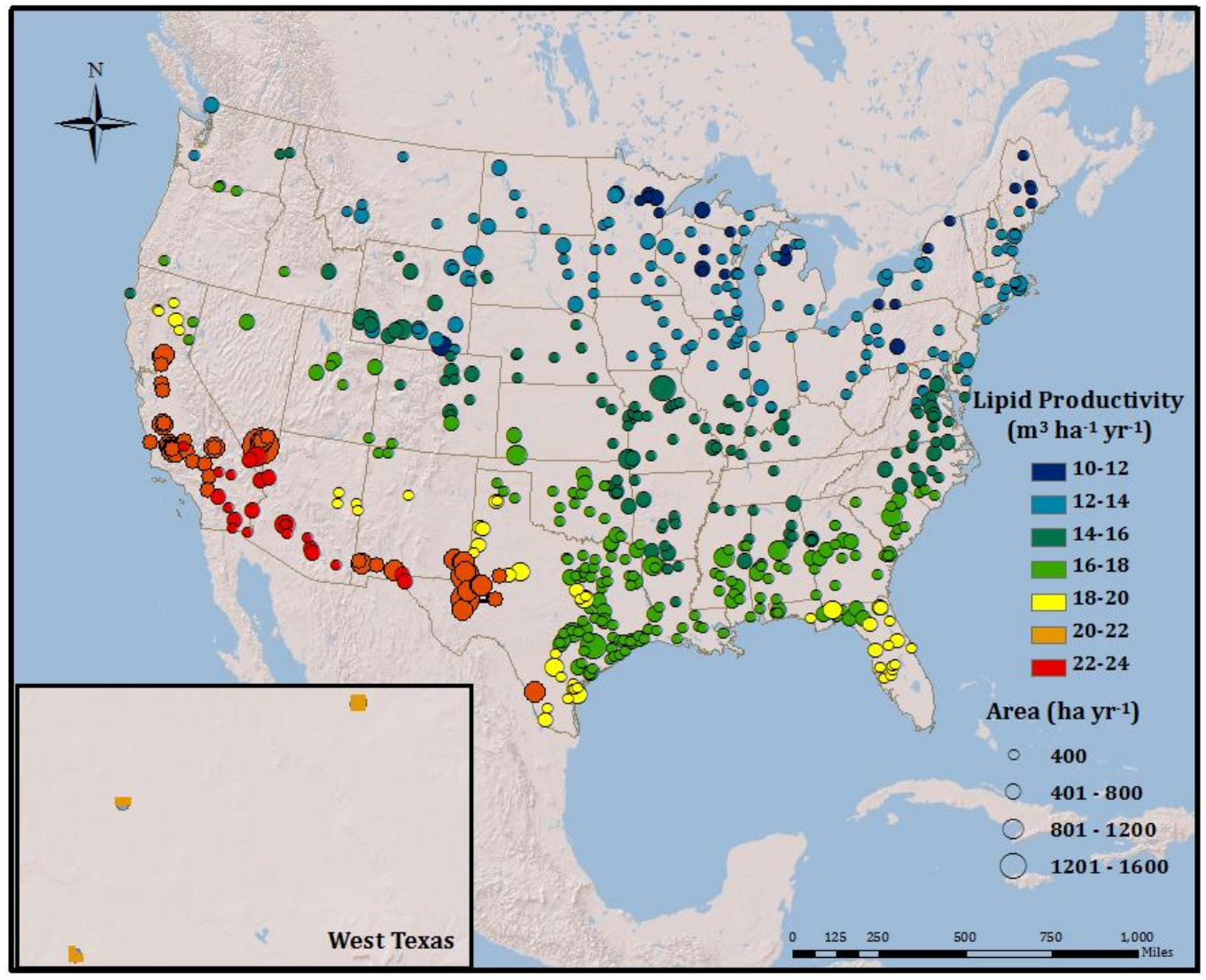

Fig. S9 Barren, forest, pasture land, <5\% slope, minimum farm size of 400 ha, $1.6 \mathrm{~km}$ buffer

Resource restrictions of barren, forest, and pasture land with less than 5\% slope, a minimum far size of 400 ha and a $1.6 \mathrm{~km}$ buffer around $\mathrm{CO}_{2}$ sources is show in Fig. S9. For this case, the maximum area within one buffer is 1600 ha, and area within each buffer is represented by different sized circles and color coded by lipid productivity potential. 


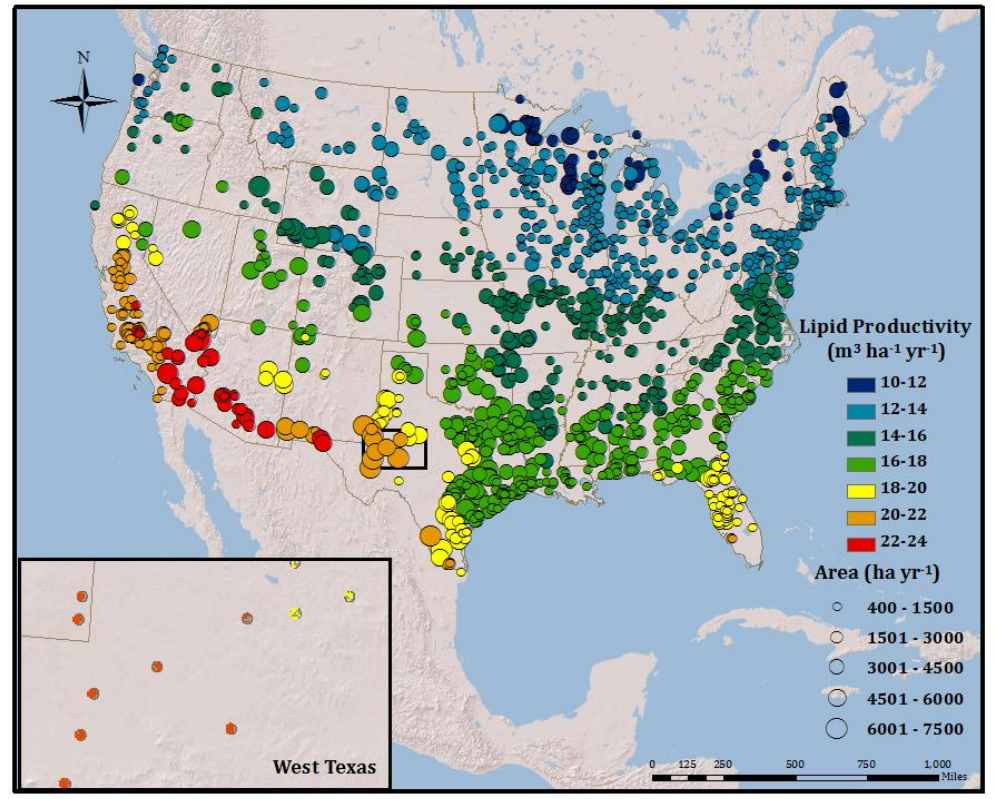

Fig. S10. Annual lipid productivity for barren, forest, and pasture land with slope less than 5\%, minimum farm size of $400 \mathrm{ha}$, and a $16 \mathrm{~km} \mathrm{CO}_{2}$ buffer radius

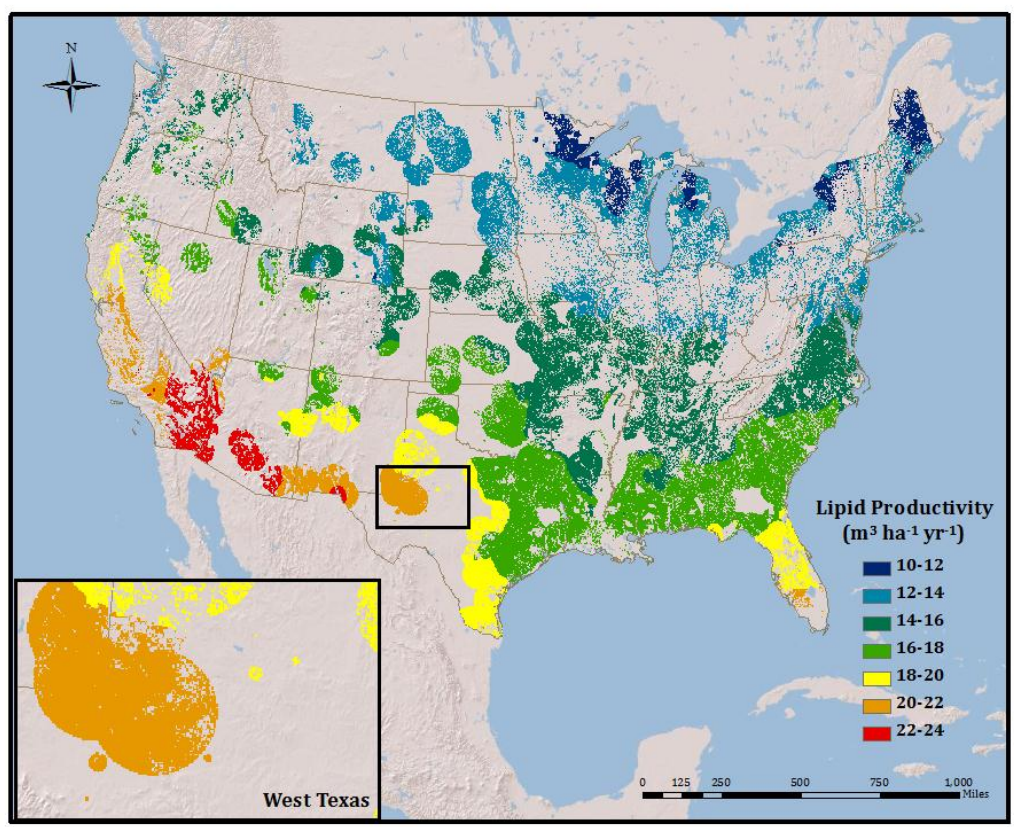

Fig. S11 Barren, forest, pasture land, $<5 \%$ slope, minimum farm size of $400 \mathrm{ha}$, and a maximum of $80 \mathrm{~km} \mathrm{CO}_{2}$ transport 
Barren, forest, and pasture land with less than 5\% slope, a minimum farm size of 400 ha and $80 \mathrm{~km}$ buffers around $\mathrm{CO}_{2}$ sources is show in Fig. S11. At certain locations, it was determined that the $80 \mathrm{~km}$ buffer radius incorporated more potential growth area than the $\mathrm{CO}_{2}$ source could support. Buffers at these locations were adjusted to more accurately depict the microalgae area possible.

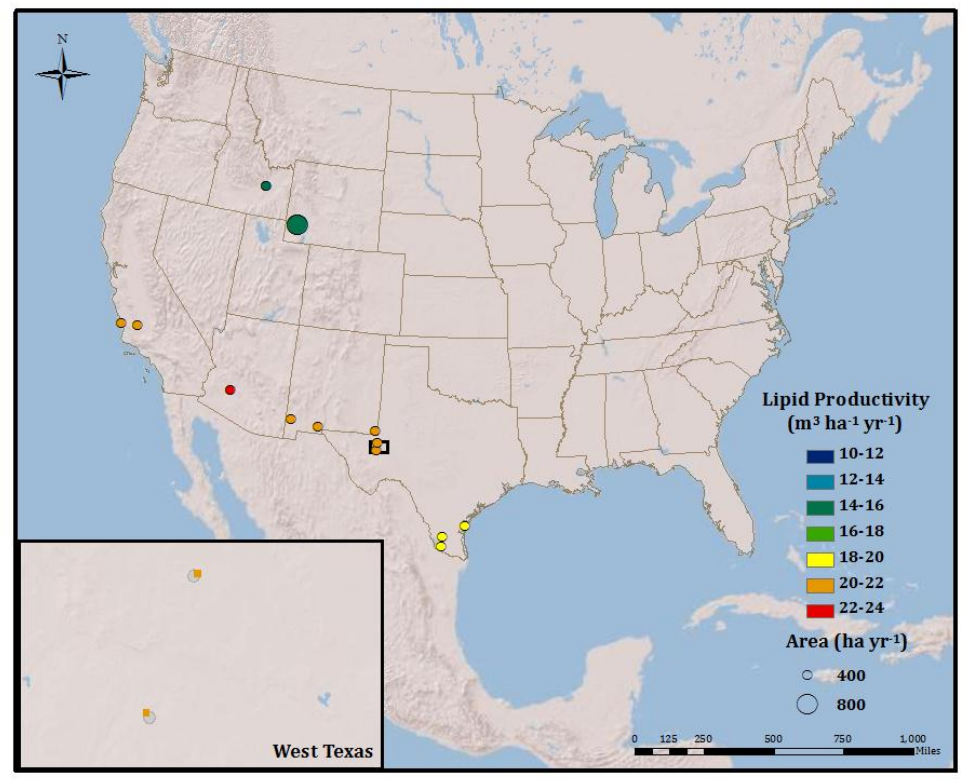

Fig. S12 Barren land, $<1 \%$ slope, minimum farm size of 400 ha, and $1.6 \mathrm{~km} \mathrm{CO}_{2}$ buffer

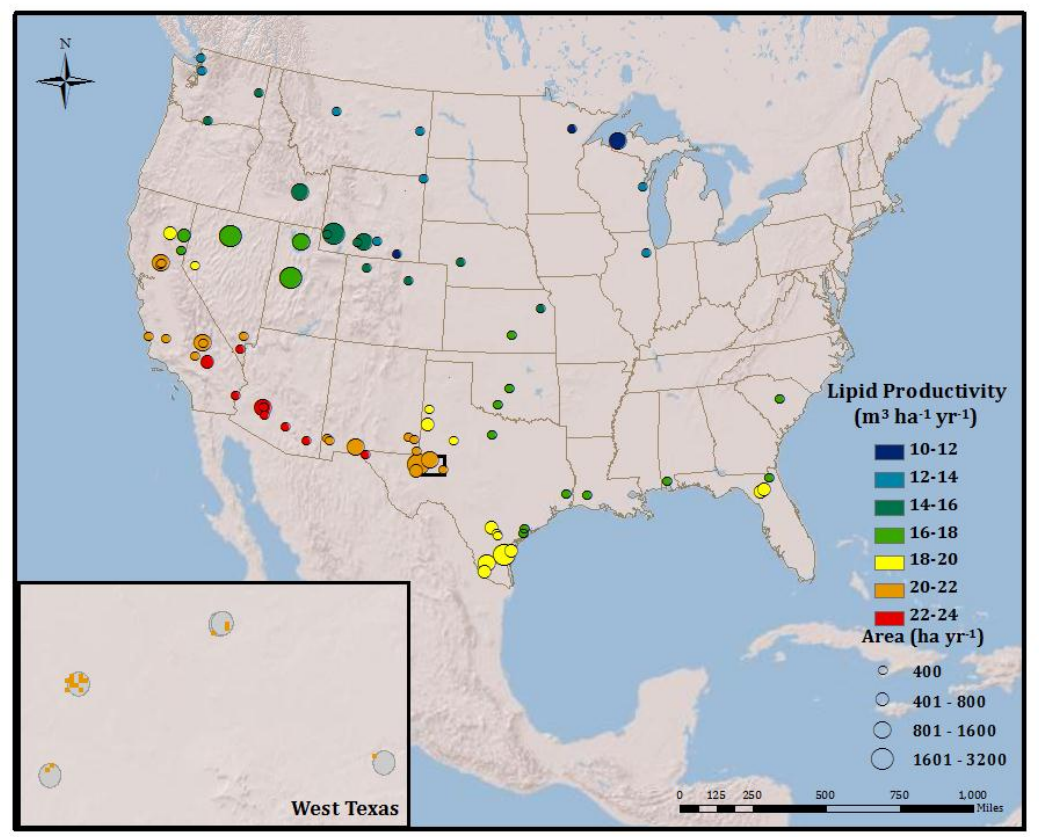

Fig. S13 Barren land, <1\% slope, minimum farm size of 400 ha, and $4.8 \mathrm{~km}$ buffer 


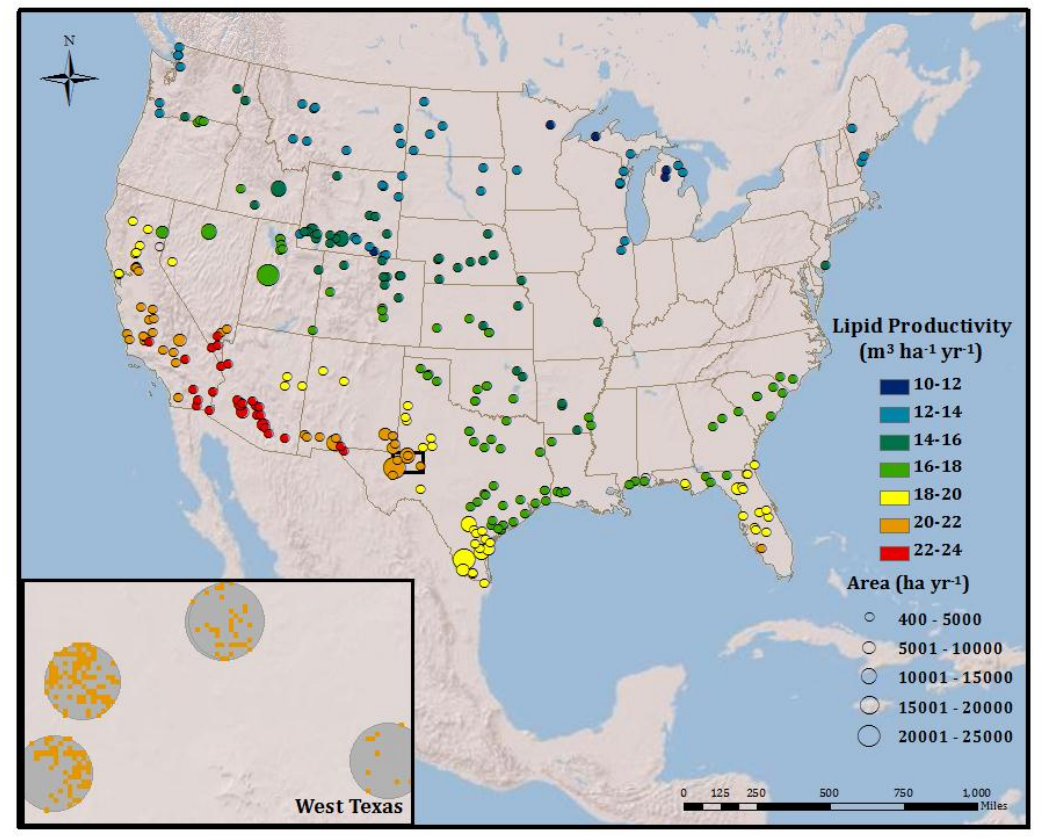

Fig. S14 Barren land, <1\% slope, minimum farm size of 400 ha, and $16 \mathrm{~km}$ buffer

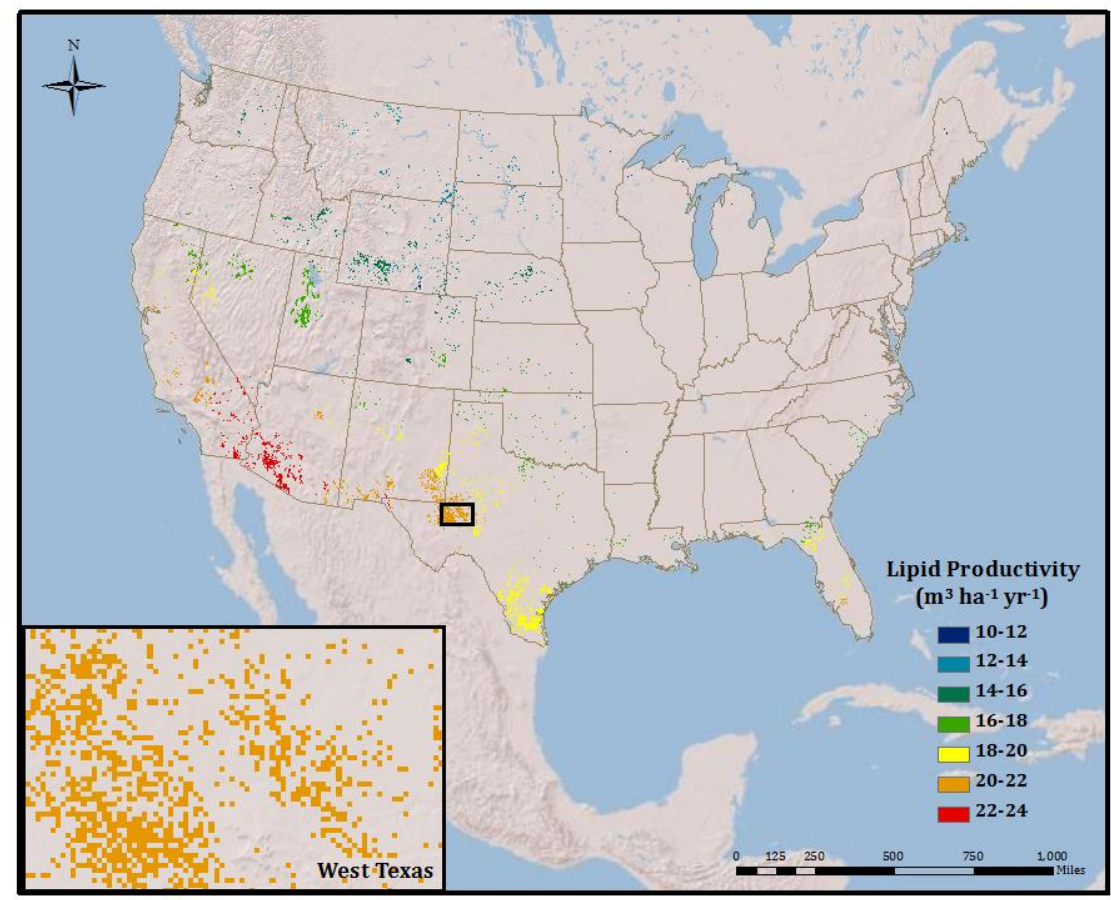

Fig. S15 Barren land, <1\% slope, minimum farm size of 400 ha, and $80 \mathrm{~km} \mathrm{CO}_{2}$ buffer 


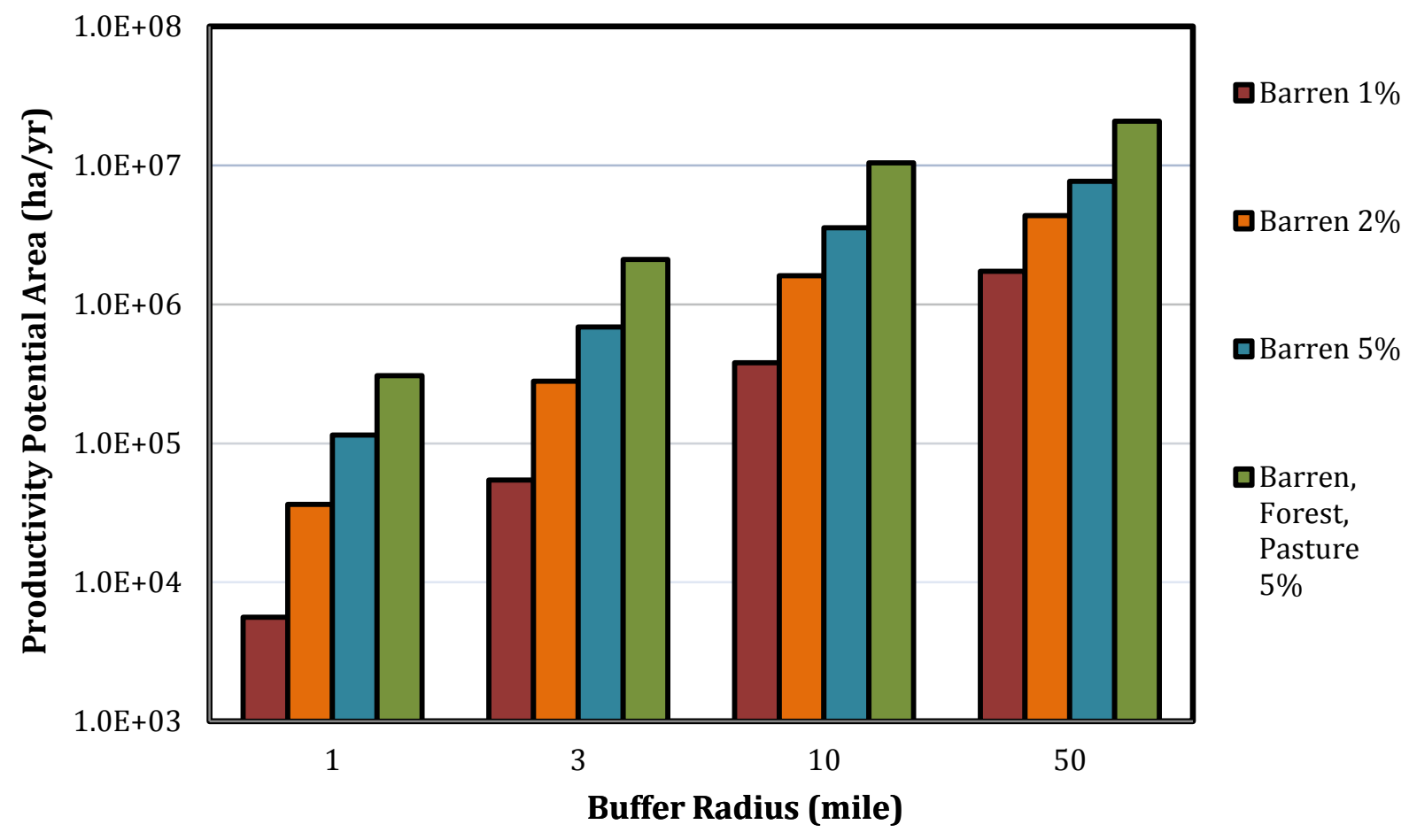

Fig. S16. Lipid productivity area for the different land restrictions and $\mathrm{CO}_{2}$ buffer radii

Lipid productivity area was determined by zonal statistics in ArcGIS. The area ArcGIS calculated was used at each $\mathrm{CO}_{2}$ location, unless it exceeded the maximum productivity values established, in which case the maximum productivity value was used. Summing the area within each buffer totaled to the lipid productivity and a comparison for the different scenarios is shown in Fig. S16, on a log scale.

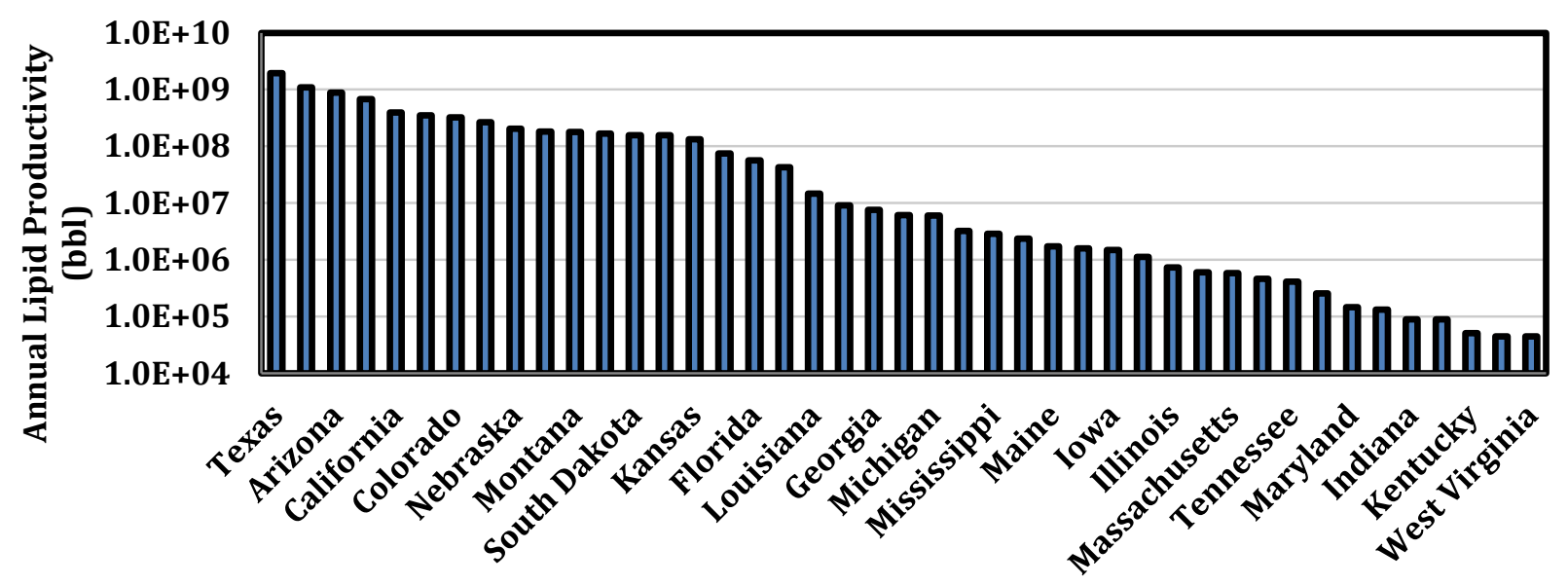

Fig. S17 Annual Lipid Productivity for barren land, with less than $2 \%$ slope and no $\mathrm{CO}_{2}$ locations considered

Annual lipid productivity for barren land with less than two percent slope is shown in Fig. S17 with no $\mathrm{CO} 2$ source locations taken into consideration. 


\section{References}

1. Quinn J, de Winter L, Bradley T (2011) Microalgae bulk growth model with application to industrial scale systems. Bioresour Technol 102 (8):5083-5092

2. Quinn JC, Yates T, Douglas N, Weyer K, Butler J, Bradley TH, Lammers PJ (2012) Nannochloropsis Production Metrics in an Scalable Outdoor Photobioreactor for Commercial Applications. Bioresour Technol 117:164-171. doi:10.1016/j.biortech.2012.04.073

3. Benemann JR, Goebel RP, Weissman JC, Augenstein DC (1982) Microalgae as a source of liquid fuels. Final Technical Report, US Department of Energy, Office of Research:DOE/ER/30014-TR

4. Benemann JR, Oswald WJ (1996) Systems and economic analysis of microalgae ponds for conversion of $\mathrm{CO}_{2}$ to biomass. Final report: . March 1996.

5. Davis R, Aden A, Pienkos PT (2011) Techno-economic analysis of autotrophic microalgae for fuel production. Applied Energy 88 (10):3524-3531

6. Frank ED, Han J, Palou-Rivera I, Elgowainy A, Wang MQ (2011) Life-cycle analysis of algal lipid fuels with the GREET model. Center for Transportation Research, Energy Systems Division, Argonne National Laboratory,

7. Wigmosta MS, Coleman AM, Skaggs RJ, Huesemann MH, Lane LJ (2011) National microalgae biofuel production potential and resource demand. Water Resour Res 47:W00H04. doi:10.1029/2010wr009966

8. Lundquist TJ, Woertz IC, Quinn NWT, Benemann JR (2010) A Realistic Technology and Engineering Assessment of Algae Biofuel Production. Energy Biosciences Institute, 